\title{
Normal and tangential behaviour of dry joints in refractory masonry
}

\author{
Rafael L. G. Oliveira ${ }^{1}$; João Paulo C. Rodrigues ${ }^{1}$; João M. Pereira ${ }^{2}$; Paulo B. Lourenço ${ }^{2}$, Hans Ulrich \\ Marschall ${ }^{3}$
}

${ }^{1}$ Civil Engineering Department, Coimbra University, Portugal.

${ }^{2}$ Institute for Sustainability and Innovation in Structural Engineering, Civil Engineering Department, Minho University, Portugal.

${ }^{3}$ RHI Magnesita, Technology Center Leoben, 8700 Leoben, Austria.

\begin{abstract}
Industrial vessels used in high temperature processes of steel and cement production are protected by refractory linings built with mortarless joints. These dry joints, formed by stacked bricks have a crucial importance on the mechanical behaviour of the lining. The stiffness and consequently the stresses generated by thermal expansion are reduced due to the joints. The present article presents the results of experimental and numerical tests on the thermomechanical behaviour of these joints. The compressive strength of the brick was assessed at ambient and high temperatures and a statistical analysis of the distribution of the bricks' shape imperfections was carried out. Several studies were carried out on the normal behaviour of the joints: classical joint closure test; bed joint closing action in a masonry wallet measured with a DIC; effects of brick's height imperfections on its loadbearing capacity; effects of brick's height imperfections on the wall's behaviour at ambient and high temperatures and a comparison between the bed and head joints behaviour. To characterize the joint's tangential behaviour at high temperatures a novel device was developed and presented.
\end{abstract}

Keywords: refractories; dry joints masonry, joint behaviour; thermomechanical properties; steel ladle 
Preprint version, Reference: Oliveira R, Rodrigues JP, Pereira JM, Lourenço PB, Marschall HU (2021), Normal and tangential behaviour of dry joints in refractory masonry. Engineering Structures, 243, 112600. https://doi.org/10.1016/j.engstruct.2021.112600

\section{Introduction}

Industrial vessels used in high temperatures processes are protected against the material they contain by refractory linings with different functions: $i$ ) barrier function: protecting industrial facilities and guaranteeing personnel safety; ii) container function: confining solid, liquid and gases in containers without altering their composition; and iii) thermal insulation function: limiting heat losses [1,2]. The working lining of steel ladles and the lining of rotary cement kilns are usually composed by refractory dry joints masonries [3 - 6]. Due to the extreme service conditions, these layers must not only withstand the high temperatures, up to $1650^{\circ} \mathrm{C}$ in the case of steel ladles and up to $1450^{\circ} \mathrm{C}$ in the case of cement kilns, but other types of actions that directly influence its thermomechanical behaviour for which premature failure should be avoided: mechanical stresses, cracking, abrasion, creep, thermal shock and corrosion $[2,7]$.

Due to the thermal gradient through the thickness of the vessel walls and the different thermal elongation of the refractory layers and the steel shell, the working lining is submitted to high compressive stresses. These may lead to failure of the linings [3] or induce creep [8 - 10]. The dry joints are defined by the contact between the bricks' surfaces, and the bricks' geometric tolerances (such as non-parallelism, non-planarity and deviations from the design dimensions) are mainly the responsible for the normal joint behaviour, while the bricks' surface roughness plays a secondary role. The dry joints have a small thickness but they play a crucial role on reducing the stresses generated in the linings, as they are able to reduce the stiffness of the lining and, consequently, they reduce significantly the stresses caused by the restrained thermal elongation $[1,3,11]$. Despite the importance of the dry joints in the performance of the refractory masonry linings, there is limited researches available on this topic in the literature.

The current lack of knowledge on the behaviour of dry joints, includes namely: the evolution of the friction angle with the temperature; the quantification of the degradation of joints under cyclic loading; the effects of bricks' height imperfections in the masonry behaviour at high temperatures. This study aims to investigate the normal and tangential behaviour of dry joints in refractory masonry, allowing to address this lack of knowledge. Aiming to evaluate the bricks' mechanical properties, two types of bricks were tested under compression at ambient and high temperatures. A compression test on stacked bricks was performed at ambient temperature aiming to determine the normal behaviour of the joints. The heterogeneity of the joint's closure curves was also analysed. Numerical models were developed to study the joints behaviour and the effects of brick shape imperfections. Finally, the tangential 
Preprint version, Reference: Oliveira R, Rodrigues JP, Pereira JM, Lourenço PB, Marschall HU (2021), Normal and tangential behaviour of dry joints in refractory masonry. Engineering Structures, 243, 112600. https://doi.org/10.1016/j.engstruct.2021.112600

behaviour of the joints was evaluated at ambient and high temperatures based on tests using an inclined plane.

\section{State of art}

In dry-stacked masonry, two geometric imperfections are fundamental for the observed behaviour: the height imperfection between different bricks $(\Delta \mathrm{H})$ and the roughness of the bricks' surface $(\Delta \mathrm{h})$, being the latter, a property related to a given brick. Gasser et al [3] performed an experimental study on the behaviour of refractory brick's dry joints. The goal of this research was to evaluate the bricks and joint' properties and define a homogenised material able to simulate the behaviour of the linings. The bricks' properties were obtained in compression tests, while the joint normal behaviour was obtained by a compression test performed in two stacked bricks. The force-displacement curve obtained experimentally for the stacked bricks shown two different stages: $i$ ) a non-linear part: corresponding to the joint closure; and ii) a linear part: corresponding to the brick's behaviour. The joint thickness may be estimated from this curve. According to [3], the relative dispersion obtained experimentally shown that crushing is affected not only by the surfaces' roughness but also by the brick shape imperfections, such as non-flatness or non-parallelism of the faces. The authors have evaluated the friction angle between the bricks at room temperature, however, the evolution of the joints properties with the temperature was not investigated.

Thanoon et al [12] proposed a mathematical model to describe the nonlinear compressive stresses in mortarless masonries in terms of joint closure (Figure 1 and Eq. 1):

$$
\sigma_{n}=a d_{n}^{b}+c d_{n}
$$

Where $\sigma_{n}$ is the normal compressive stress $\left(\mathrm{N} / \mathrm{mm}^{2}\right), d_{n}$ is the gap or closing deformation (mm) and $a$, $b$ and $c$ are constants determined from experimental results. The normal tangent stiffness of the joint, $k_{n}$, may be obtained by differentiating Eq. 1, as shown in Eq. 2 :

$$
k_{n}=a b d_{n}^{b-1}+c
$$

The equation proposed by Thanoon et al [12] was used to simulate the normal behaviour of the dry joints in the numerical simulations of section 5 


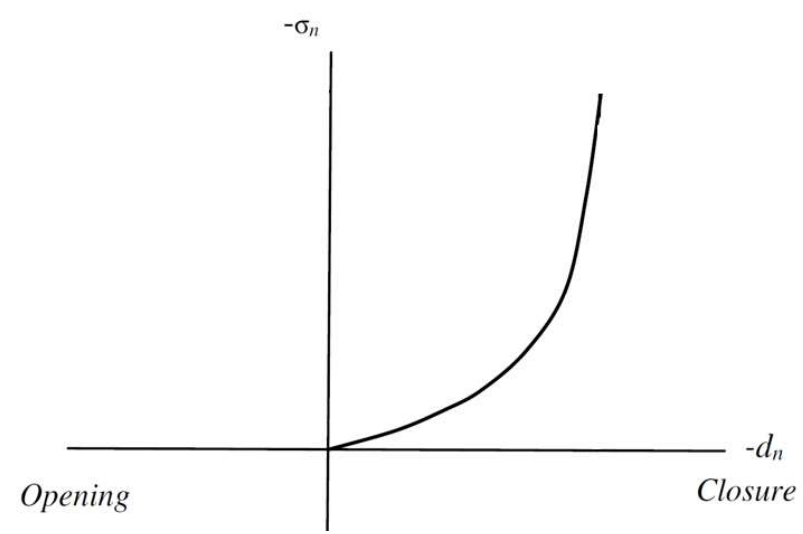

Figure 1 - Criterion for closure of dry joints - Modified from [12]

Andreev et al [11] extended the research performed by Gasser et al [3] on the compressive behaviour of dry joints in refractory masonries. The authors performed compressive tests in prisms formed by magnesia-carbon and magnesia-chromite bricks in a wide temperature range. They highlighted that the exponential form of the joint closure curve is a result of the gradual crushing of initially non-parallel surfaces. The tests have shown that the temperature influences the joint closure by changing the stiffness of the material and reducing the initial gap by thermal elongation. The contact area between the bricks was found to be proportional to the applied stress. The authors observed that the joint thickness is not constant along the joint due to surface roughness, bricks' shape variations and nonparallelism of faces. The use of the Digital Image Correlation allowed the joint closure measurements in different areas along the joint, evidencing the elevated scattering on the joints' behaviour.

Allaoui et al [1] expanded the research performed by Andreev et al [11]. The authors evaluated the roughness of the bricks' surface and found the arithmetical mean roughness was about $12 \pm 2 \mu \mathrm{m}$ and the maximum height of the profile between successive peaks and valleys was about $85 \pm 15 \mu \mathrm{m}$. The results shown that the gap between bricks is caused mainly by the lack of planarity of the brick surfaces. The authors highlighted that the process of joint closure involves roughness crushing and adjustment of surfaces, which is a strongly heterogeneous, orthotropic and a nonlinear process. The authors observed local joint opening during the first stage of the global joint closure in one sample, caused by rigid body motion that induced rotation of the contacting bricks. The DIC technique [13, 14] allowed a detailed study on the local and global joint closure. However, the authors have not evaluated the joint closure behaviour at elevated temperature nor the tangential behaviour of the joints.

Zahra et al [15] evaluated the effects of contact surface unevenness on the behaviour of dry stackable blocks used in civil construction, mostly caused by the presence of random interstices and coarse 
aggregates in the blocks' surface. Matrix based tactile surface sensors (MBTSS) were used to precisely determine the contact pressure at the brick interfaces, which exhibited several high-pressure points over the contact surfaces, leading to a non-uniform distribution. The high-pressure points are observed even for higher loads, most likely caused by high strength coarse aggregates. The authors proposed techniques to mitigate the unevenness contact conditions, however, these techniques seem less interesting in the case of refractory masonries due to the high temperatures in service.

Ngapeya et al [16] evaluated the effects of bricks' height imperfection on the behaviour of dry-stacked masonry. As observed by Agaajani [17], the bricks' height imperfection follows a Gaussian law. The tolerances of production of the bricks studied were $\pm 2 \mathrm{~mm}$. The bricks' height imperfections led to an uneven stress distribution in the wall, because the loading and support conditions of the bricks were not perfect. Consequently, it was possible to observe significant stress concentrations in some points of the wall, evidenced by the vertical load flow. Due to the unevenness stress distribution in the bricks, the authors defined five load cases for a single brick depending on the support and loading conditions (Figure 2). Numerical models were used to evaluate the influence of the uneven stress distribution in the compressive strength of the bricks and in the loadbearing capacity of the wall.

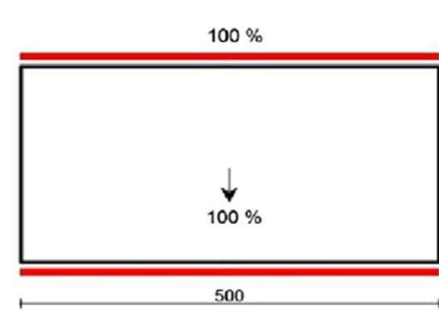

Loading case I

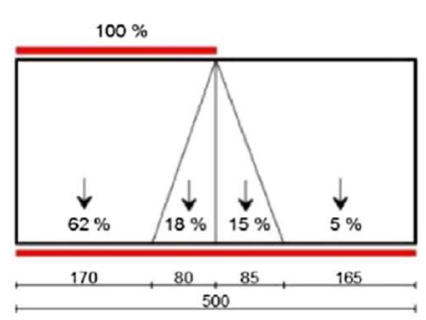

Loading case II

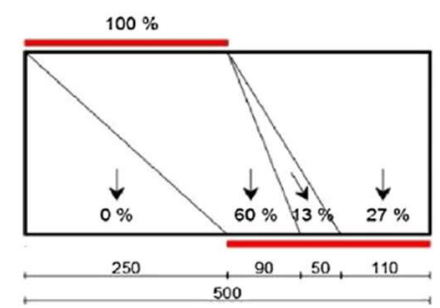

Loading case III

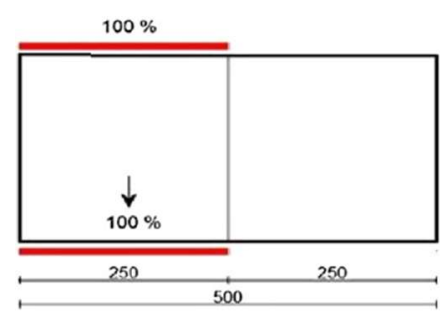

Loading case IV

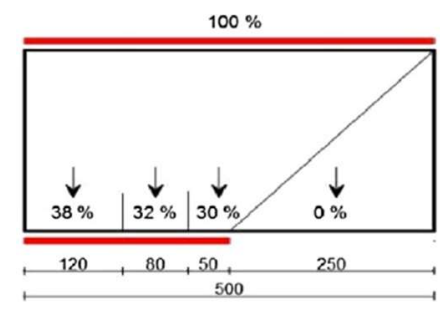

Loading case $\mathrm{V}$

Figure 2 - Different support and loading conditions for a single brick [Adapted from 16] 
The behaviour of joints in mortarless masonry is ruled by the Coulomb friction law [3, 4]. For masonries with mortar the Mohr-Coulomb failure criterion with tensile cut-off may be used [18]. EN 1052-3:2002 [19] is widely used to determine the initial shear strength at ambient temperature for joints with mortar. The triplet shear tests may also be used to characterize dry joints. However, it is a challenge to perform this test at high temperatures, because it requires the application of loads in two orthogonal directions. The Slant Shear test was successfully used to characterize the brick/mortar interface at ambient and high temperatures [18], nevertheless, the slant shear test can't be used in the case of dry joints.

When dealing with mortarless masonry, only the friction coefficient (or friction angle) needs to be identified. A simple test is the use of an inclined plane, with increasing rotation, which makes possible to measure the initial angle of sliding [3]. This test can be easily performed at high temperatures.

The friction between bricks plays an important role in the stabilization of the lining, mainly in cold conditions. In cement furnaces, the movement of refractory bricks causes opening of the joints and, as a consequence, individual bricks or even sections of the lining may fall out $[5,20]$. In numerical simulations of mortarless masonries, the friction coefficient between bricks is usually taken as a temperature independent parameter [3, 4, 20 - 23]. This is because there is a lack of data in the literature related to the evaluation of the friction coefficient at high temperatures.

\section{Material characterization}

\subsection{Material}

Alumina-spinel bricks are being increasingly used in industrial vessels for industry applications, especially in the working lining of steel ladles, due to the requirements of ultralow carbon content metallurgy. High-alumina bricks are also used in the lining of rotary cement kilns [6, 20, 24]. The chemical composition of these bricks used in this research is presented in Table 1.

Table 1 - Chemical composition of alumina-spinel bricks according to EN ISO 12677

\begin{tabular}{cccc}
\hline $\mathrm{Al}_{2} \mathrm{O}_{3}$ & $\mathrm{Fe}_{2} \mathrm{O}_{3}$ & $\mathrm{SiO}_{2}$ & $\mathrm{MgO}$ \\
\hline $94.0 \%$ & $0.1 \%$ & $0.3 \%$ & $5.0 \%$ \\
\hline
\end{tabular}

Determination on fired substance $\left(1025^{\circ} \mathrm{C} / 1877^{\circ} \mathrm{F}\right)$ 
Preprint version, Reference: Oliveira R, Rodrigues JP, Pereira JM, Lourenço PB, Marschall HU (2021), Normal and tangential behaviour of dry joints in refractory masonry. Engineering Structures, 243, 112600. https://doi.org/10.1016/j.engstruct.2021.112600

The production process of the refractory bricks involves complex processes that include shaping process (pressing) and thermal treatments (firing). As reported in the literature, the position of the bricks in the furnace during firing affects their mechanical properties [25]. The pressing procedure also has an impact on the mechanical properties, as the cold crushing strength and refractoriness under load (RUL) of samples extracted from the direction of pressing are different from the ones obtained perpendicular to the pressing direction [26 - 28]. The creep properties of refractories also have a significant scatter depending on the direction of loading and on the position of the sample inside the brick $[9,29]$.

Three different bricks, using the same composition, produced for different industrial applications were used in this study (Fig. 5). Brick $A$ has an edged shape to fit the circular shape of industrial vessels, which is commercially produced and widely used in steel ladles. Bricks $B$ and $C$ have rectangular shape, being used in tunnel kilns (e.g. for ceramic or glass). Brick $\mathrm{C}$ is of smaller size and was used in the compressive test of the masonry wallets.
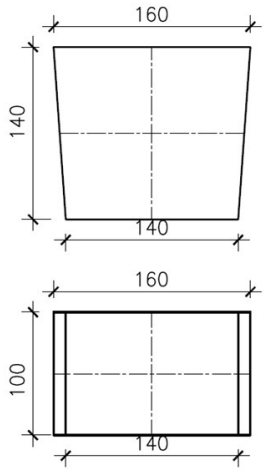

a)
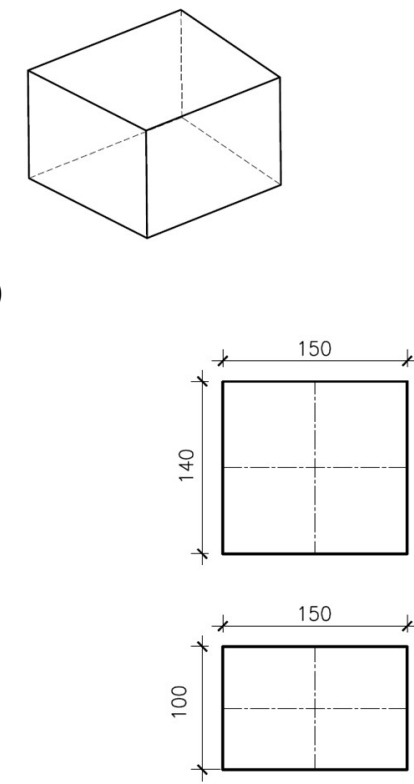
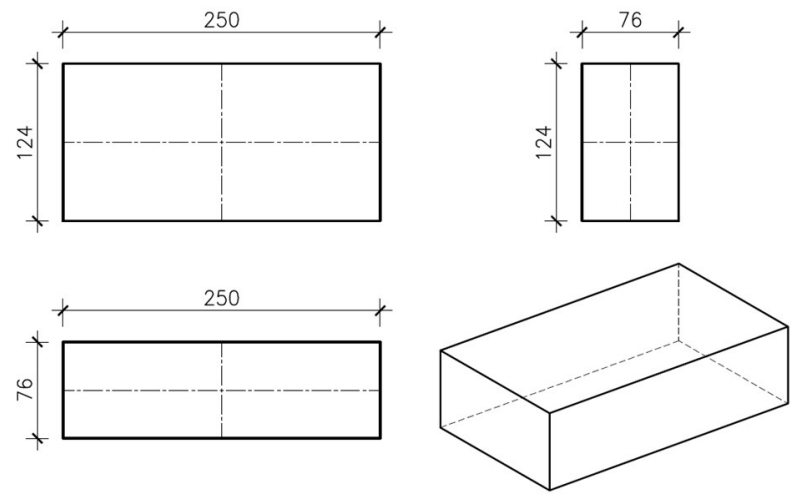

b)

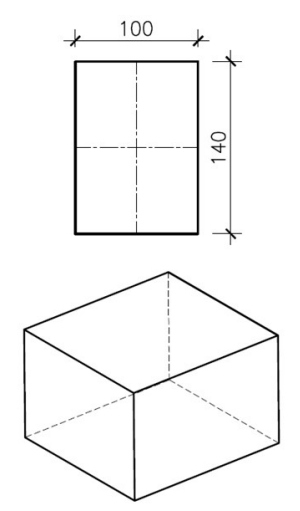

c)

Figure 3 - Brick shapes: a) Brick A: Edged; b) Brick B: Rectangular; b) Brick C: Rectangular: 
Preprint version, Reference: Oliveira R, Rodrigues JP, Pereira JM, Lourenço PB, Marschall HU (2021), Normal and tangential behaviour of dry joints in refractory masonry. Engineering Structures, 243, 112600. https://doi.org/10.1016/j.engstruct.2021.112600

\subsection{Brick shape imperfections}

As reported in literature, the bricks shape imperfections play the most important role in the dry joint behaviour [1, 3, 11, 16]. Agaajani [17] observed that bricks' dimension deviations follow a statistic distribution of a Gaussian curve.

The bricks' dimensions were evaluated for all directions of the brick using a calliper rule. Three measurements were performed for each direction and the mean value was taken. The imperfections (defined by the differences between the measured and the prescribed dimension) are reported in Figure 6. In the directions orthogonal to the pressing, the imperfections vary from $-1.1 \mathrm{~mm}$ up to $+0.8 \mathrm{~mm}$ in good correlation with the fabrication tolerances indicated by the supplier $( \pm 1.0 \mathrm{~mm})$, with a small standard deviation (maximum is $\sigma=0.41 \mathrm{~mm}$ in the thickness direction). In the direction of pressing, the fabrication tolerances are higher $( \pm 2.0 \mathrm{~mm})$ and higher imperfections were observed, ranging from $-2.4 \mathrm{~mm}$ up to $+1.4 \mathrm{~mm}$, with a higher standard deviation $(\sigma=0.84 \mathrm{~mm})$. The deviations in the pressing direction are highly influenced by the procedure and by the amount of the material placed in the moulds. 
Preprint version, Reference: Oliveira R, Rodrigues JP, Pereira JM, Lourenço PB, Marschall HU (2021), Normal and tangential behaviour of dry joints in refractory masonry. Engineering Structures, 243, 112600. https://doi.org/10.1016/j.engstruct.2021.112600

$$
\begin{aligned}
& \mu=0.01 \mathrm{~mm} \\
& \sigma=0.26 \mathrm{~mm}
\end{aligned}
$$

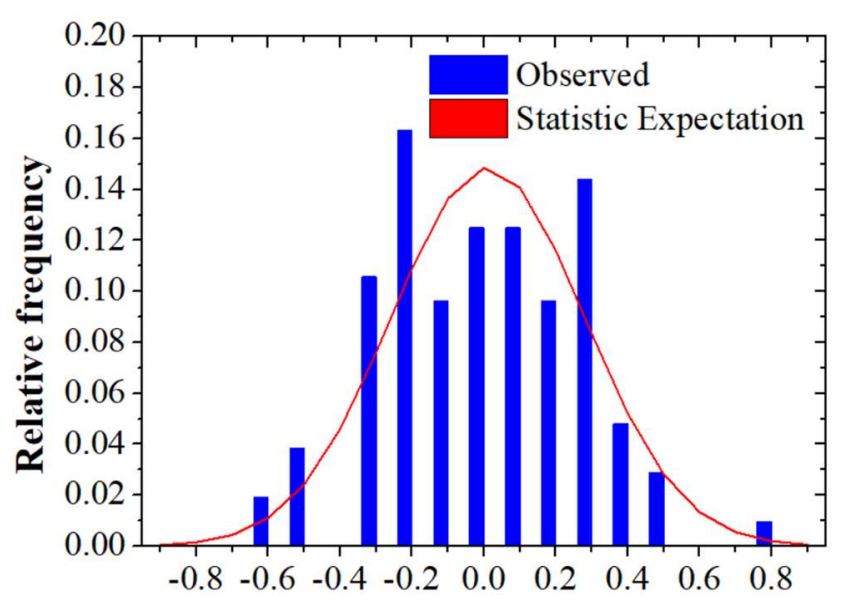

Imperfection [m m]

a) Orthogonal to pressing / Direction $\mathrm{X}(100 \mathrm{~mm})$

$$
\begin{aligned}
\mu & =0.15 \mathrm{~mm} \\
\sigma & =0.84 \mathrm{~mm}
\end{aligned}
$$

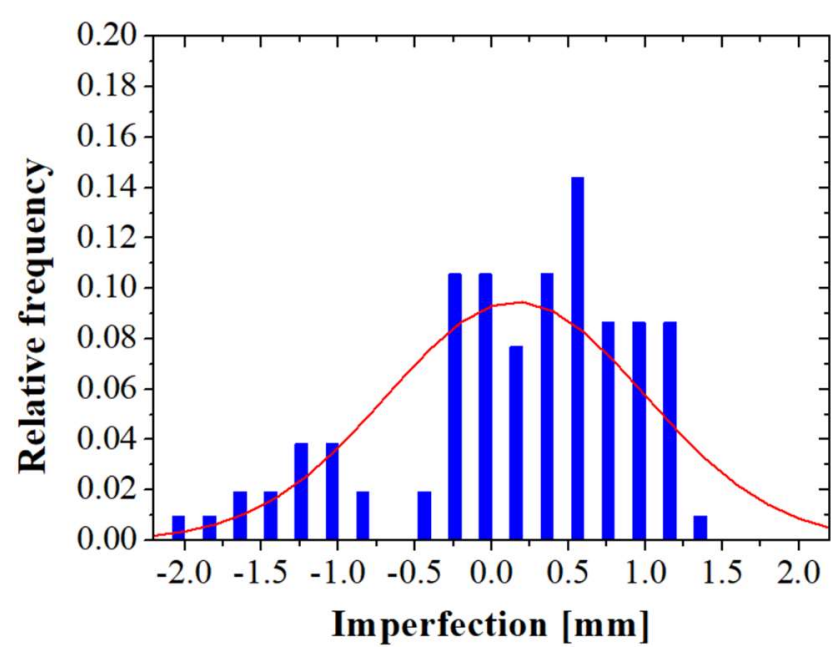

c) Parallel to pressing / Direction Z $(150 \mathrm{~mm})$

$$
\begin{aligned}
\mu & =0.05 \mathrm{~mm} \\
\sigma & =0.41 \mathrm{~mm}
\end{aligned}
$$

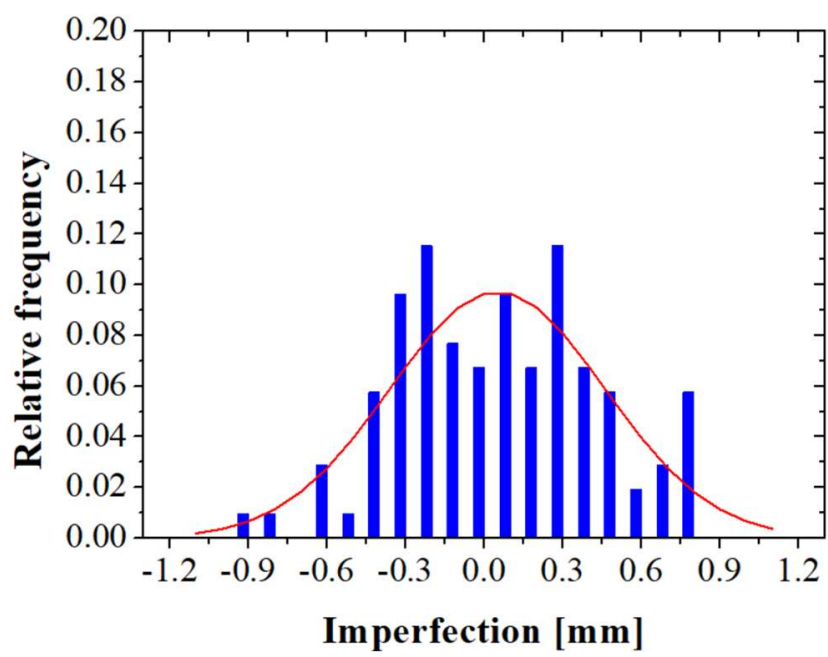

b) Orthogonal to pressing - Direction Y (140 mm)
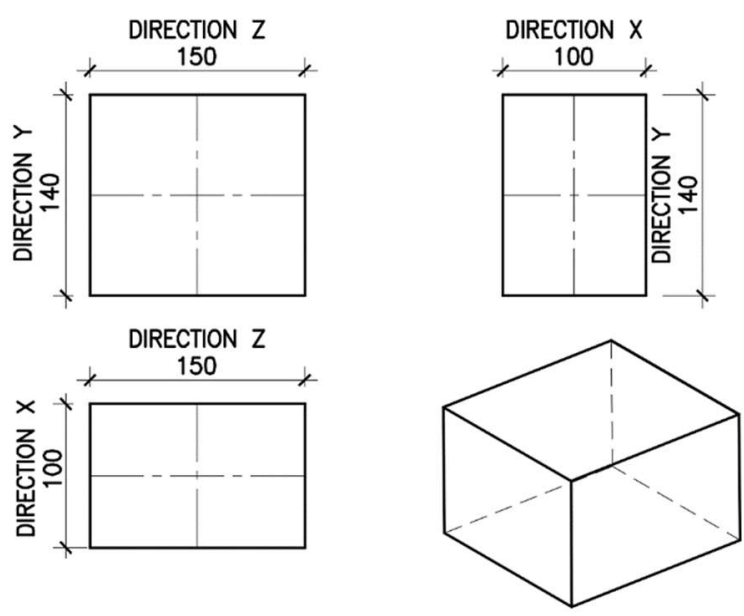

d) Brick's prescribed dimensions

Figure 4 - Brick shape imperfections for brick C: a) height; b) thickness; c) length; d) Brick's prescribed dimensions ( $\mu$ indicates the average of the deviation from the prescribed dimension and $\sigma$ indicates the standard deviation of the deviation) 
Preprint version, Reference: Oliveira R, Rodrigues JP, Pereira JM, Lourenço PB, Marschall HU (2021), Normal and tangential behaviour of dry joints in refractory masonry. Engineering Structures, 243, 112600. https://doi.org/10.1016/j.engstruct.2021.112600

\section{Compressive strength tests}

Compressive tests have been carried out to determine the compressive strength of the material $\left(f_{c}\right)$ at ambient and high temperatures (Table 2). Bricks A or B were used in the fabrication of specimens of the four tests series. The specimens were cylindrical and had $50 \mathrm{~mm}$ diameter. The heights of the specimens are different, as a result of the different geometries of the bricks used in their fabrication and different coring directions. Consequently, the specimens have different slenderness ratios, which may have some influence on their compressive strength.

Table 2 - Bricks' compressive strength tests

\begin{tabular}{ccccc}
\hline Test Series & Brick & Temperature & Coring direction & Sample dimensions \\
\hline S01 & A & Ambient temperature & Pressing & $\varnothing 50 \times 120 \mathrm{~mm}$ \\
S02 & B & Ambient temperature & Pressing & $\varnothing 50 \times 100 \mathrm{~mm}$ \\
S03 & B & Ambient temperature & Orthogonal to pressing & $\varnothing 50 \times 50 \mathrm{~mm}$ \\
S04 & B & $600^{\circ} \mathrm{C}, 800^{\circ} \mathrm{C}$ and $1000^{\circ} \mathrm{C}$ & Pressing & $\varnothing 50 \times 100 \mathrm{~mm}$ \\
\hline
\end{tabular}
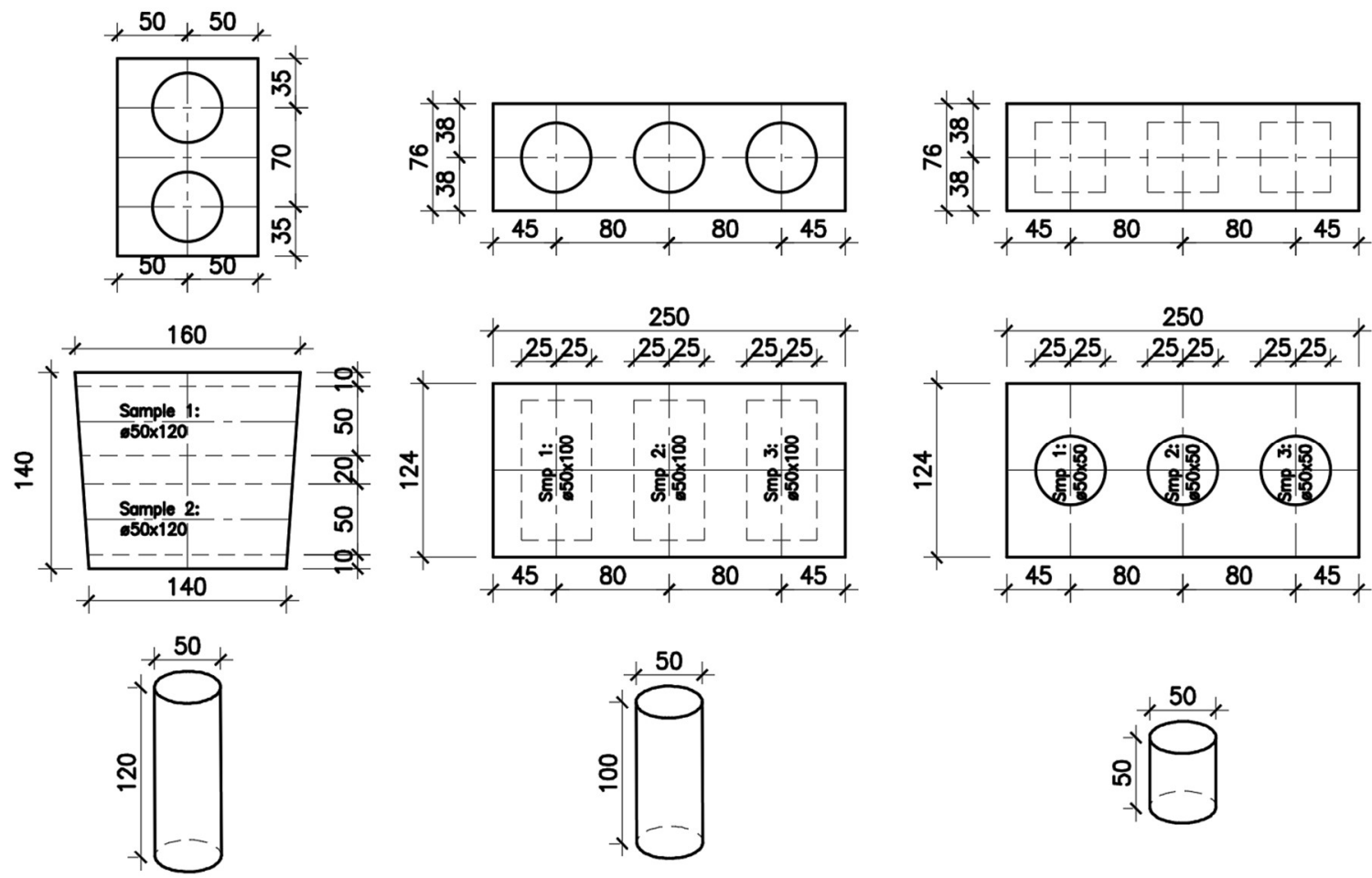

a)

b)

c)

Figure 5 - Specimens dimensions: a) Series S01, b) Series S02 and S04; c) Series S03 
As stated above, the test specimens consisted of cylinders extracted from the bricks. They were cored in the block units using a diamond drill. Afterwards, the specimens were cut to size using a diamond saw, grinded, and dried in an electric furnace at $105^{\circ} \mathrm{C}$ for 24 hours. After the griding, the specimens' surfaces were smooth. The coring direction and the specimens dimensions are detailed in Figure 5. Series S01, S02 and S03 were tested at ambient temperature. The specimens were placed in the testing machine, and compressed under displacement control at the rate of $0.01 \% / \mathrm{s}$.

Series S04 was tested at high temperatures $\left(600^{\circ} \mathrm{C}, 800^{\circ} \mathrm{C}\right.$ and $\left.1.000^{\circ} \mathrm{C}\right)$. The specimens were placed in the testing machine that applied under force control an initial pre-compression load of $2 \mathrm{kN}$. A heating rate of $5^{\circ} \mathrm{C} / \mathrm{min}$ was chosen, based on experiments performed by other researchers [30 - 34]. After the testing temperature was reached, a dwell time of one hour was considered in order to homogenize the temperature within the specimen. After this dwell time, the compression test was carried out under displacement control at the same rate of $0.01 \% / \mathrm{s}$. In order to confirm that the temperature was homogeneous, thermocouples were installed in different positions of the specimens in Series 4. The thermocouple measurements indicated that at the time of the application of the mechanical load, the specimen was indeed subjected to homogeneous temperature.

The overall results of the compression tests can be seen in Table 3. The average compressive strength $\left(f_{\text {c avg }}\right)$ of brick A tested in the pressing direction (series S01) was 29.2 MPa. The average compressive strength $\left(f_{c a v g}\right)$ of brick B tested in the pressing direction (series S02) and orthogonal to the pressing direction (series S03) were 32.4 MPa and 27.4 MPa, respectively. Series S04 was tested for different temperatures: $600^{\circ} \mathrm{C}, 800^{\circ} \mathrm{C}$ and $1.000^{\circ} \mathrm{C}$. The average compressive strength $\left(f_{c}\right.$ avg $)$ for these temperatures are 24.2MPa, 34.4 $\mathrm{MPa}$ and 27.0 $\mathrm{MPa}$, respectively. $\sigma$ indicates the standard deviation of the test results. 
Preprint version, Reference: Oliveira R, Rodrigues JP, Pereira JM, Lourenço PB, Marschall HU (2021), Normal and tangential behaviour of dry joints in refractory masonry. Engineering Structures, 243, 112600. https://doi.org/10.1016/j.engstruct.2021.112600

Table 3 - Compressive strength test results

\begin{tabular}{|c|c|c|c|c|c|c|}
\hline Test Series & Direction & Temperature & Specimen & $\begin{array}{c}f_{c} \\
{[\mathrm{MPa}]}\end{array}$ & $\begin{array}{c}f_{\text {cavg }} \\
{[\mathrm{MPa}]}\end{array}$ & $\begin{array}{r}\sigma\left(\mathbf{f}_{\mathrm{c}}\right) \\
{[\mathrm{MPa}}\end{array}$ \\
\hline \multirow{4}{*}{ S01 } & \multirow{4}{*}{ Pressing } & \multirow{4}{*}{$20^{\circ} \mathrm{C}$} & S1.01 & 34.4 & \multirow{4}{*}{29.2} & \multirow{4}{*}{3.20} \\
\hline & & & S1.02 & 29.4 & & \\
\hline & & & S1.03 & 26.2 & & \\
\hline & & & S1.04 & 26.8 & & \\
\hline \multirow{3}{*}{ S02 } & \multirow{3}{*}{ Pressing } & \multirow{3}{*}{$20^{\circ} \mathrm{C}$} & S02.01 & 35.6 & \multirow{3}{*}{32.4} & \multirow{3}{*}{3.65} \\
\hline & & & S02.02 & 34.4 & & \\
\hline & & & S02.03 & 27.3 & & \\
\hline \multirow{3}{*}{ S03 } & \multirow{3}{*}{$\begin{array}{l}\text { Perpendicular to } \\
\text { Pressing }\end{array}$} & \multirow{3}{*}{$20^{\circ} \mathrm{C}$} & S03.01 & 27.5 & \multirow{3}{*}{27.4} & \multirow{3}{*}{0.16} \\
\hline & & & S03.02 & 27.6 & & \\
\hline & & & S.03.03 & 27.2 & & \\
\hline \multirow{9}{*}{ S04 } & \multirow{3}{*}{ Pressing } & \multirow{3}{*}{$600^{\circ} \mathrm{C}$} & S04.600.01 & 25.9 & \multirow{3}{*}{24.2} & \multirow{3}{*}{2.38} \\
\hline & & & S04.600.02 & 25.9 & & \\
\hline & & & S04.600.03 & 20.8 & & \\
\hline & \multirow{3}{*}{ Pressing } & \multirow{3}{*}{$800^{\circ} \mathrm{C}$} & S04.800.01 & 35.8 & \multirow{3}{*}{34.4} & \multirow{3}{*}{1.69} \\
\hline & & & S04.800.02 & 35.3 & & \\
\hline & & & S04.800.03 & 32.0 & & \\
\hline & \multirow{3}{*}{ Pressing } & \multirow{3}{*}{$1000^{\circ} \mathrm{C}$} & S04.1000.01 & 24.2 & \multirow{3}{*}{27.0} & \multirow{3}{*}{4.08} \\
\hline & & & S04.1000.02 & 32.8 & & \\
\hline & & & S04.1000.03 & 24.1 & & \\
\hline
\end{tabular}

Figure 6 presents the stress-strain curves for S01, S02 and S03 test series. The anisotropic behaviour of the material is observed by comparing test series S02 and S03, although these two series have different aspect ratios for the specimens. Still, a significant difference in the compressive strength and in the Young's modulus is found. It is noted also that the peak strains (less than $0.1 \%$ ) are relatively low when compared to other concrete-like civil engineering materials. As expected, the compressive strength of the brick is higher in the pressing direction. The scatter obtained on the results (an average coefficient of variation about 10\%) is expected for refractory materials, as the setting method and positions of the bricks in the kiln during firing may affect its mechanical properties [25 - 28]. 
Preprint version, Reference: Oliveira R, Rodrigues JP, Pereira JM, Lourenço PB, Marschall HU (2021), Normal and tangential behaviour of dry joints in refractory masonry. Engineering Structures, 243, 112600. https://doi.org/10.1016/j.engstruct.2021.112600

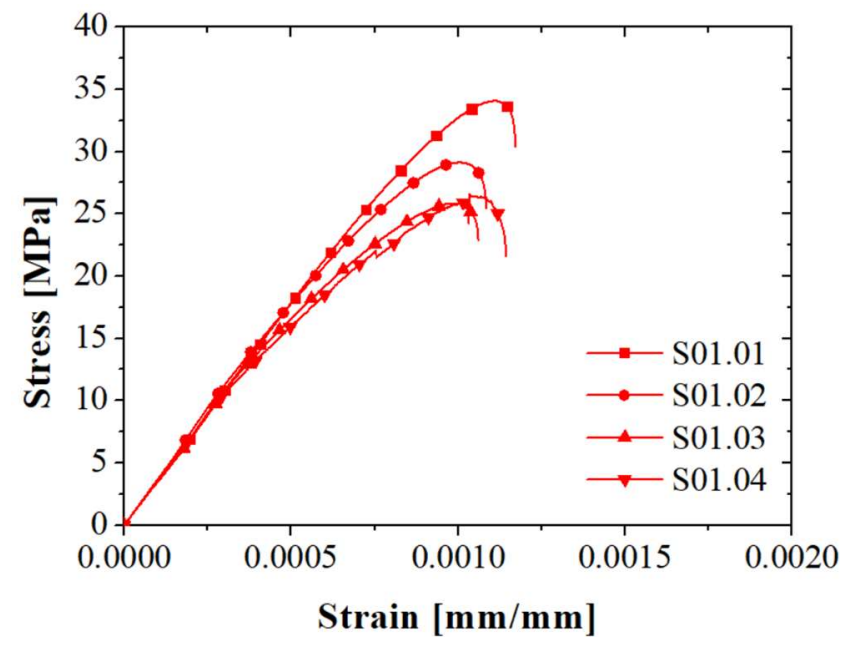

a)

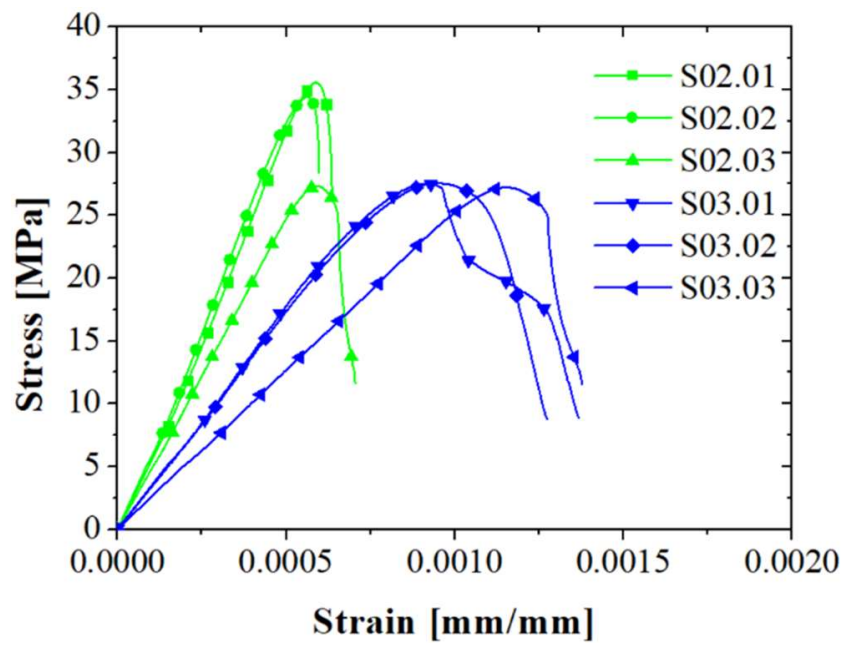

b)

Figure 6 - Stress-strain curves: a) S01, b) S02 and S03

\section{Joint normal behaviour tests}

The joint normal behaviour has been evaluated by using experimental and numerical tests. A classical joint closure test was performed here and the bed joint closing curve was measured for a masonry wallet using DIC. The effect of bricks' height imperfections on the masonry behaviour was studied numerically, at ambient and high temperatures, by using results available in the literature. A comparison between the bed and head joints behaviour was also performed.

\subsection{Classical joint closure test}

The joint closure test allows to assess the normal behaviour of the dry joints. In this test, two stacked bricks are compressed and the displacements are recorded. The joint thickness may be obtained based on the force-displacement diagram. The adopted specimens consisted of a masonry prism composed by two stacked bricks with dry joints. The brick type B was used (Figure 5b). The bricks were cut using a circular diamond saw, and the final dimensions of the specimens were $124 \times 124 \mathrm{~mm}$ by 76 $\mathrm{mm}$ in height. The dry joint was formed by two refractory bricks stacked together, therefore, the original faces of the brick were tested and the cut faces were positioned in the orthogonal direction. The final dimensions of the prism were $124 \times 124 \mathrm{~mm}$ by $152 \mathrm{~mm}$ in height. The joint closure tests were performed at ambient conditions. A multipurpose Servo Hydraulic Universal Testing Machine $\mathrm{W}+\mathrm{B}$ Series LFV of $600 \mathrm{kN}$ maximum capacity was used (Figure 7a). The displacements were measured with an Epsilon extensometer connected to the machine. 
Preprint version, Reference: Oliveira R, Rodrigues JP, Pereira JM, Lourenço PB, Marschall HU (2021), Normal and tangential behaviour of dry joints in refractory masonry. Engineering Structures, 243, 112600. https://doi.org/10.1016/j.engstruct.2021.112600

A compressive load was applied under load control at the constant rate of $0.5 \mathrm{kN} / \mathrm{s}$, up to $150 \mathrm{kN}$. At this load level, the average compressive stress was 9.76 MPa and a linear behaviour was expected at the bricks. The thickness of the joints was estimated based on the force-displacement curve obtained in the joint closure test, considering the intersection of the linear section of the curve, with the horizontal axis in the plot [3].

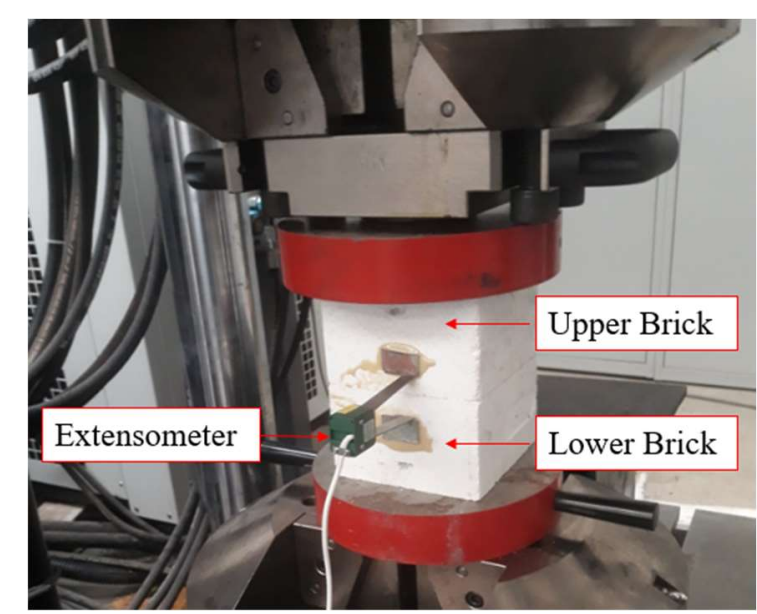

a)

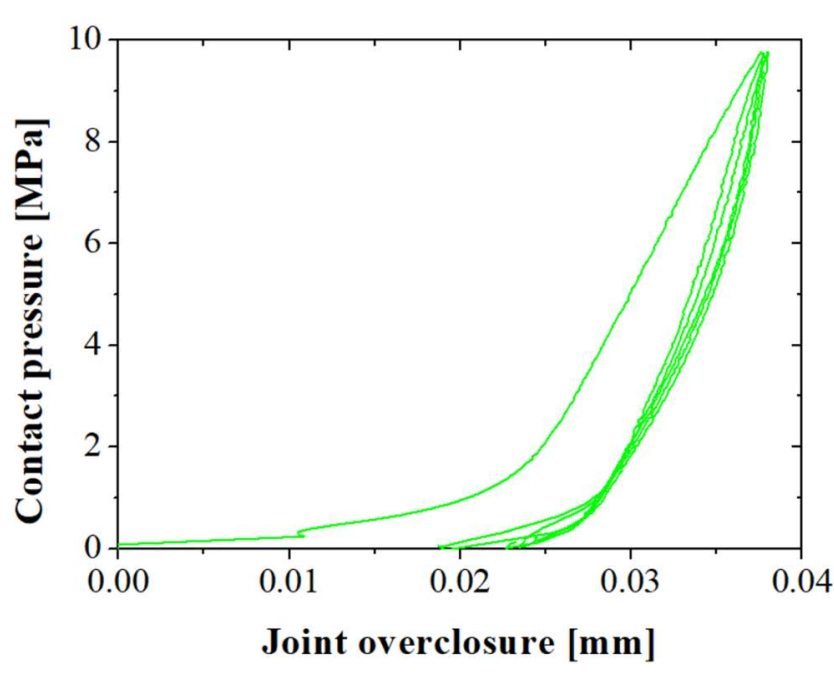

b)

Figure 7 - Joint closure test a) Experimental setup, b) Joint closure curve

Three load cycles were applied to the specimen. At the first cycle, it is possible to identify a behaviour much different from the subsequent cycles due to adjustment of the contact surface at the joint, and the initial joint thickness was $0.022 \mathrm{~mm}$. For the second and third load cycles, a more similar behaviour was observed, and the joint thickness reduced then to only $0.007 \mathrm{~mm}$. This reduction is caused by joint degradation due to crushing of initial non-flat surfaces of the bricks. This happens along the first load cycle, as observed by other authors $[1,3,11,35,36]$ and as shown in the joint closure test. The joint degradation increases the contact area between the bricks, leading to an increase of the initial stiffness of the prism.

\subsection{Heterogeneity in the joint behaviour}

When the bricks are dry-stacked to form a masonry wallet, the imperfection of the bricks dimensions is not corrected by a mortar layer. In this situation it is not possible to ensure the levelling of the courses and voids are present. Consequently, the bricks' imperfections have a significant impact on the load 
Preprint version, Reference: Oliveira R, Rodrigues JP, Pereira JM, Lourenço PB, Marschall HU (2021), Normal and tangential behaviour of dry joints in refractory masonry. Engineering Structures, 243, 112600. https://doi.org/10.1016/j.engstruct.2021.112600

transfer through the masonry and the supporting conditions of each brick, as shown in Figure 8 a). The heterogeneity of the joint closing along the length of the wall is being analysed in this section. The masonry wall presented in Figure 8 b) was experimentally evaluated under compressive load. Bricks C were used to construct the wall.

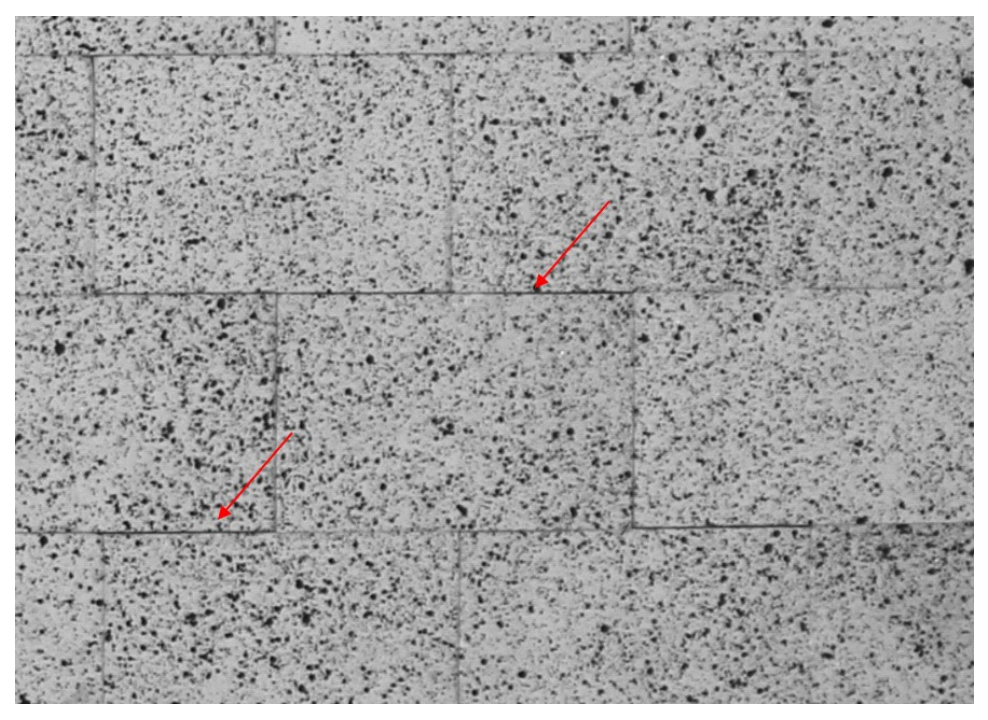

a)

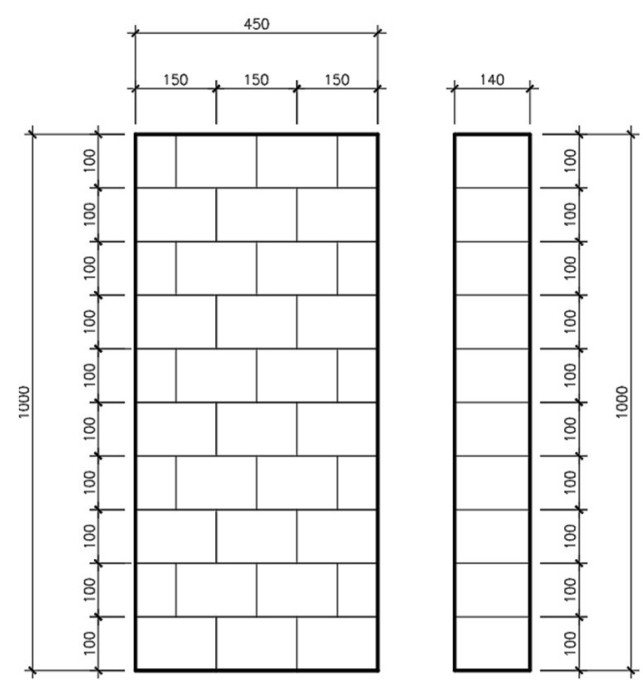

b)

Figure 8-a) Bed joints imperfections in mortarless refractory masonry; b) Dimensions of the masonry wallet

Joint closure curves were assessed here by means of a DIC technique for different points in a masonry wallet top horizontal joint (Figure 9a). Figure 9b presents the curves for different points in the wall and compares with the curve obtained in the classical joint closure test. It is possible to identify a significant scattering on the curves obtained by the DIC in different locations. This is a direct result of the different conditions on the support and load of each brick, caused by the bricks' shape imperfections. It is also noted that this behaviour is three-dimensional, even if only one face of the wall is measured with the DIC. The average of the DIC curves provides a significantly less stiff response than the curve obtained from the classical test, because the bricks in the masonry wallet are arranged in a more complex way than in a prism, with a non-continuous vertical joint and several bricks in a course. Consequently, the shape imperfections of the bricks introduce larger initial joint thicknesses and a stronger impact on the joint behaviour. 
Preprint version, Reference: Oliveira R, Rodrigues JP, Pereira JM, Lourenço PB, Marschall HU (2021), Normal and tangential behaviour of dry joints in refractory masonry. Engineering Structures, 243, 112600. https://doi.org/10.1016/j.engstruct.2021.112600

Therefore, joint closure test results need to be used carefully, as the initial joint thickness measured in a single joint stacked bond test may significantly deviate from the one present in masonry walls or panels.

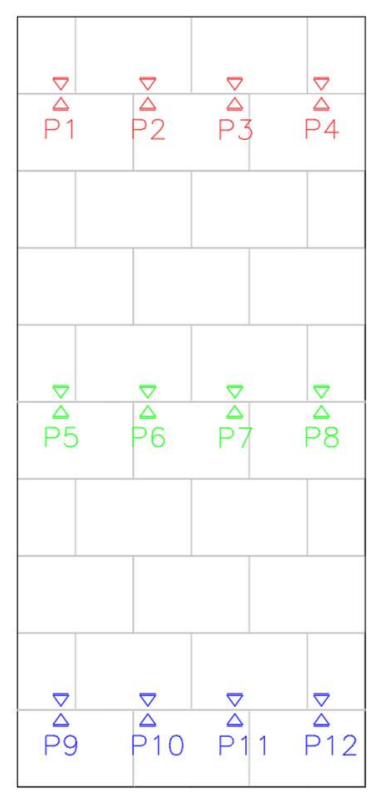

a)

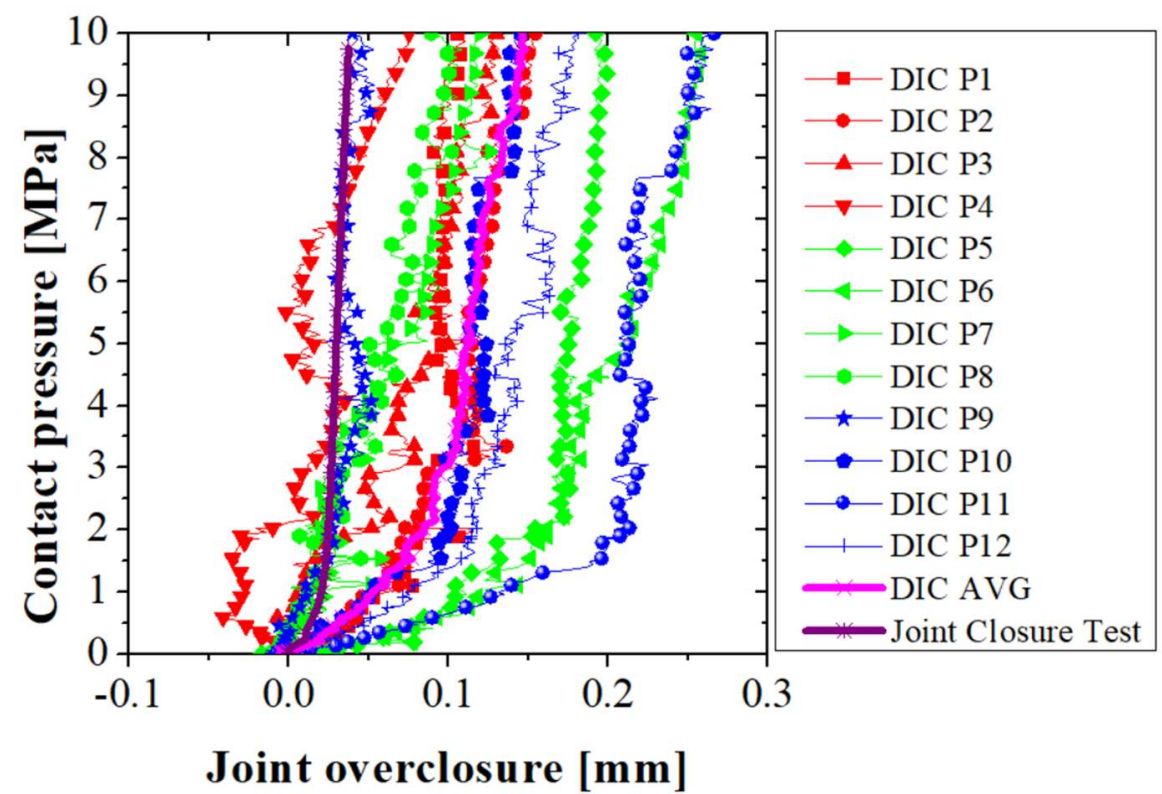

b)

Figure 9 - Heterogeneity in joint's normal behaviour: a) Locations; b) Joint closure curves

\subsection{Effects of the imperfections in height on the brick's behaviour at ambient temperature}

Ngapeya et al [16] defined five load cases to study the behaviour of a brick under different load and support conditions. As stated, these load cases occur because the masonry blocks do not have constant height and there is no mortar layer between the courses to ensure levelling. These load cases were adapted to refractory bricks and extended in the present study to consider also the bricks with "banana shape", as observed in some of the configurations of the dry joints. For this purpose, a numerical model was developed to assess the bricks loadbearing capacity and to determine the crack pattern expected for the bricks.

\subsubsection{Numerical model}

The numerical analyses presented in this work were performed using the Finite Element (FE) software Abaqus [37]. The Concrete Damage Plasticity (CDP) model was used. This model allows failure under compressive crushing and tensile cracking. The CDP model is a modification of the Drucker-Prager 
model $[38,39]$, where the shape of the failure surface in the deviatoric plane does not need to be a circle and it is defined by the parameter $K_{c}$. This parameter can be defined as a ratio of the distances between the hydrostatic axis and, respectively, the compression meridian and the tension meridian in the deviatoric plane. This parameter was taken as 0.667 , as recommended in [37]. Similarly, the dilation angle $(\psi)$ was taken as $20^{\circ}$, the eccentricity $(\varepsilon)$ defines the rate at which the flow potential approaches the asymptote (tends to a straight line as the eccentricity tends to zero) and was taken as 0.10 , the ratio of the initial equibiaxial compressive yield stress $\left(f_{b 0}\right)$ to initial uniaxial compressive stress $\left(f_{c 0}\right)$ as 1.16 and the viscosity parameter as 0.02 , used to improve the convergence rate in the softening regime. The Young's modulus obtained in series S03 was used for this study. The density of the material was measured experimentally. The tensile strength $\left(f_{t}\right)$ and fracture energy $\left(G_{f}\right)$ were obtained by the wedge split test [41]. Table 4 presents the full mechanical properties adopted in the numerical model. The bricks $\mathrm{C}$ were used in this study. The masonry wall was discretized with 8-node solid elements (C3D8R elements). This type of element is a three-dimensional continuum hexahedral brick element with reduced integration, hourglass control and linear interpolation, with three degrees of freedom per node. Friction between the bricks was taken into account (see 6.3)

Table 4 - Parameters of the alumina spinel brick

\begin{tabular}{lc}
\hline Young's modulus $(\boldsymbol{E})$ & $28500 \mathrm{MPa}$ \\
\hline Density & $3130 \mathrm{~kg} / \mathrm{m}^{3}$ \\
\hline Dilatation angle $(\boldsymbol{\psi})$ & $20^{\circ} \mathrm{C}$ \\
\hline Eccentricity $(\boldsymbol{\varepsilon})$ & 0.10 \\
\hline $\boldsymbol{f}_{\boldsymbol{b} 0} / \boldsymbol{f}_{\boldsymbol{c} \boldsymbol{0}}$ & 1.16 \\
\hline $\boldsymbol{K}_{\boldsymbol{c}}$ & 0.667 \\
\hline Viscosity parameter & 0.02 \\
\hline $\boldsymbol{f}_{\boldsymbol{c}}[\mathbf{M P a}]$ & 32.4 \\
\hline $\boldsymbol{f}_{\boldsymbol{t}}[\mathbf{M P a}]$ & 4.3 \\
\hline $\boldsymbol{G}_{\boldsymbol{f}}\left[\mathbf{J} / \mathrm{m}^{\mathbf{2}}\right]$ & 111.7 \\
\hline
\end{tabular}

\subsubsection{Results and discussions}

Table 5 presents the studied loading cases, including the applied loading and support conditions. The paths of stress flow, given by the minimum principal stresses, and the expected crack pattern, given 
Preprint version, Reference: Oliveira R, Rodrigues JP, Pereira JM, Lourenço PB, Marschall HU (2021), Normal and tangential behaviour of dry joints in refractory masonry. Engineering Structures, 243, 112600. https://doi.org/10.1016/j.engstruct.2021.112600

by the equivalent plastic strains, are presented. The results were plotted in the most stressed point of each case.

In loading case 1 , the brick is fully supported and loaded over the whole surface, therefore, it is able to reach $100 \%$ of its loadbearing capacity. For load case 2 , the brick is loaded only in half of its top surface and due to the flow of forces the brick is able resist $51.2 \%$ of the full capacity. Loading case 3, as stated by Ngapeya et al [16], is the worst scenario, with the stresses distributed only in the middle of the brick, and, due to shear, it can only withstand $10.8 \%$ of the full capacity. In loading case 4 , the brick and its loading are supported, at the same side, by only half of its length. Therefore, it can develop $41.8 \%$ of the full loadbearing capacity. In loading case 5 , which it is similar to loading case 2 , the brick is loaded in the whole top surface but supported only by half of its bottom surface, consequently it can develop up to $38.5 \%$ of its full capacity. In loading case 6 , the brick is fully loaded, but supported only by the edges (banana shaped bricks). In this case, the brick can develop up to $67.9 \%$ of its full capacity. In loading case 7, the brick also has a banana shape, and is loaded only in the central part and supported by the edges. In this case, the brick can withstand $32.8 \%$ of its compressive strength. 
Preprint version, Reference: Oliveira R, Rodrigues JP, Pereira JM, Lourenço PB, Marschall HU (2021), Normal and tangential behaviour of dry joints in refractory masonry. Engineering Structures, 243, 112600. https://doi.org/10.1016/j.engstruct.2021.112600

Table 5 - Loading cases by brick's support and loading conditions

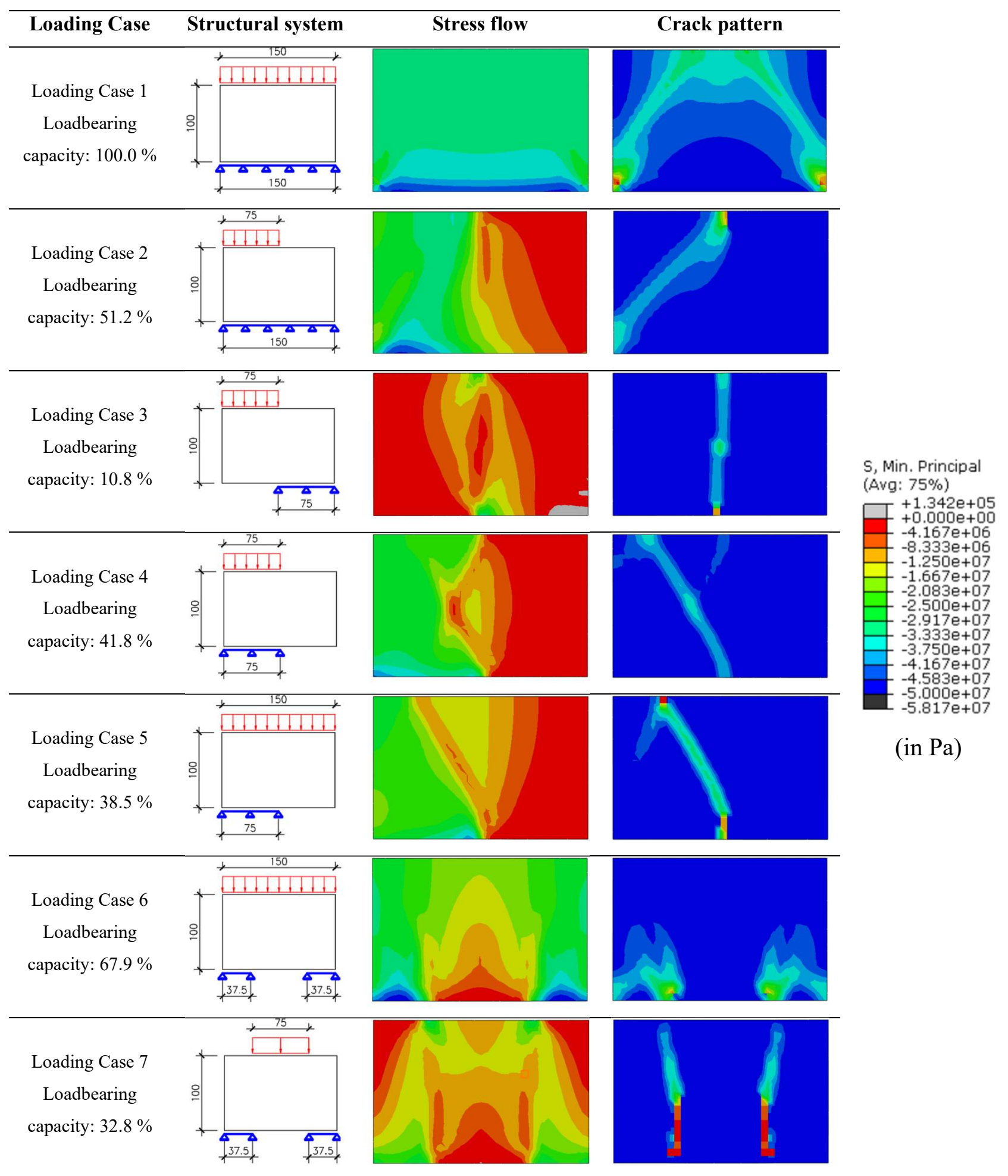

The compressive stress-strain curves of the different configurations are presented in Figure 10. The stress concentrations are evidenced by the reduction of the linear part of the curve. In loading case 1 , 
Preprint version, Reference: Oliveira R, Rodrigues JP, Pereira JM, Lourenço PB, Marschall HU (2021), Normal and tangential behaviour of dry joints in refractory masonry. Engineering Structures, 243, 112600. https://doi.org/10.1016/j.engstruct.2021.112600

the brick is fully supported and loaded, therefore, its apparent stiffness is the same of the material. In the other loading cases, the brick's apparent Young's modulus is significantly smaller than the real one of the material. Consequently, the observed difference between the stiffness of the masonry panel and the stiffness of the individual brick, may be associated with an uneven stress distribution.

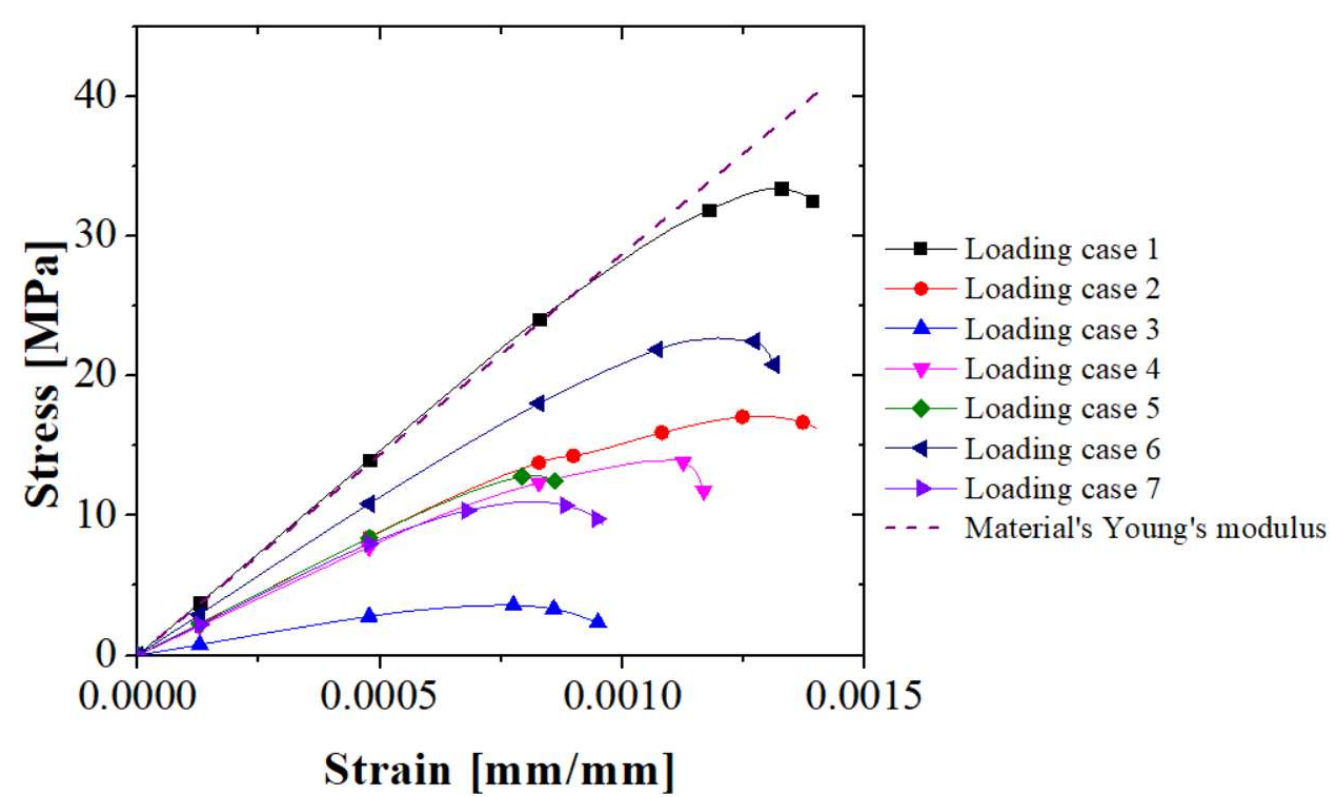

Figure 10 - Bricks stress-strain curves for loading cases 1 to 7

Figure 11 presents the comparison between the crack patterns numerically and experimentally (obtained with masonry wallets) predicted. A correlation between the crack patterns in the wall and the different simulations can be clearly observed.
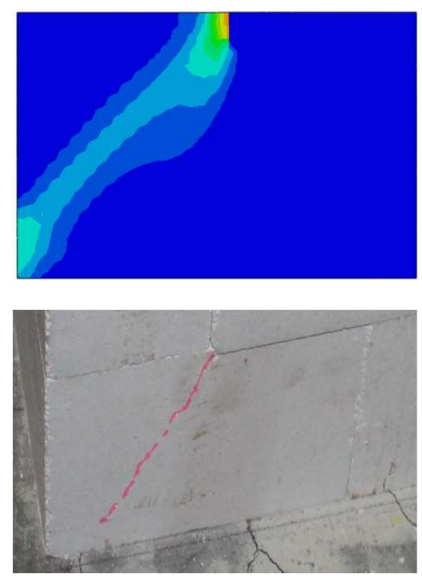

Loading case 2
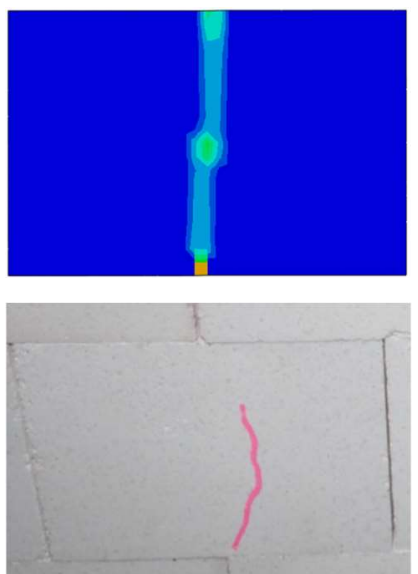

Loading case 3
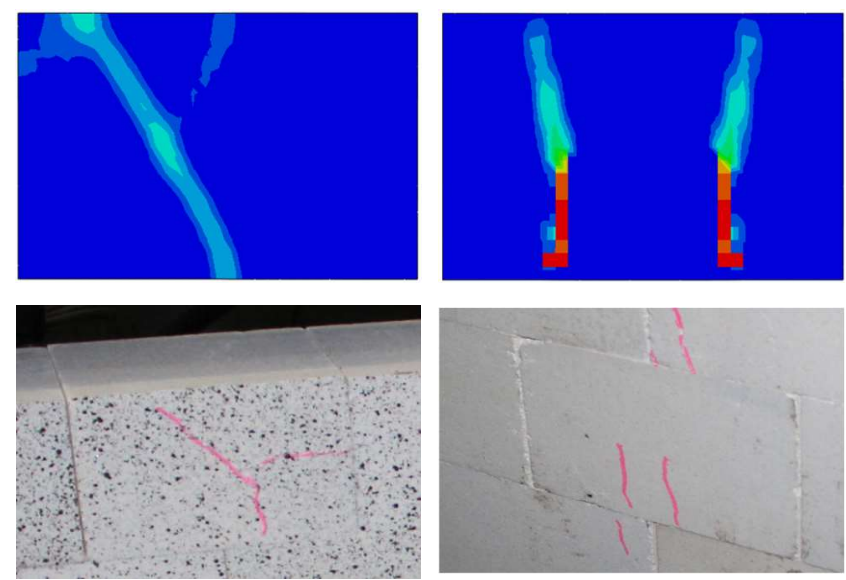

Loading case 4

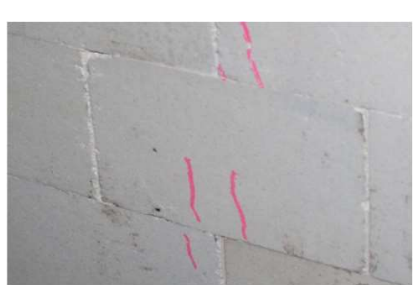

Loading case 7

Figure 11 - Crack's pattern: Numerical predictions vs experimental results 
Preprint version, Reference: Oliveira R, Rodrigues JP, Pereira JM, Lourenço PB, Marschall HU (2021), Normal and tangential behaviour of dry joints in refractory masonry. Engineering Structures, 243, 112600. https://doi.org/10.1016/j.engstruct.2021.112600

\subsection{Effects of the brick's imperfections in height in the wall behaviour at ambient and high temperatures}

As stated, in mortarless masonry, the bricks' height imperfections $(\Delta H)$ lead to unevenness stress distribution in the wall. Ngapeya et al [16] evaluated the influence of $\Delta H$ in the mechanical behaviour of the wall. A numerical model was developed to investigate the load flow in a wall. The authors identified stress concentrations caused by these differences and quantified their effects on the loadbearing capacity of the wall. This study is expanded here to analyse the influence of brick's imperfections in height in the refractory walls at ambient and high temperatures.

\subsubsection{Numerical model}

Lourenço et al [40] specified that the numerical modelling of masonry structures may be performed adopting different approaches, being these: a) detailed micro-modelling, in which block units and mortar are represented by continuous elements and the unit-mortar interface is represented by discontinuous elements (or interaction between elements); b) simplified micro-modelling, where expanded units are represented by continuous elements and the behaviour of joints and mortar-joints interfaces is lumped in discontinuous elements; and c) macro-modelling, where a homogeneous continuous material is used to represent the behaviour of the block units, mortar and interfaces. The micro-modelling requires higher computational resources but leads to more accuracy in the simulations, consequently, this strategy was chosen in this numerical study. Moreover, the micromodelling is the best strategy to simulate the influence of the brick's height.

The numerical analyses presented in this work were, again, performed using the Finite Element (FE) software Abaqus [37]. The geometry of the model is shown in Figure 12. The bricks imperfections were randomly generated based on the statistical distribution shown in Figure $4 \mathrm{a}$ with the aid of an spreadsheet. The dry joints were automatically found by the software and modelled as surface-tosurface contact interactions. The equation proposed by Thanoon et al [12] was used to represent the different joints thickness considered are presented in Figure 13a, these curves aim to account the differences in brick's height.

The masonry wall was discretized with 8-node solid elements (C3D8R elements). The final mesh was generated automatically by Abaqus software and was rather refined, 18900 elements and 26800 nodes were used, as shown in Figure $12 \mathrm{~b}$. 
Different analyses were performed, considering three temperatures (ambient temperature, $1300^{\circ} \mathrm{C}$ and $1500{ }^{\circ} \mathrm{C}$ ) and two load levels (3MPa and 5MPa). For the models at ambient temperature, the CDP model was used, with the parameters indicated in Table 4. For the simulations at high temperatures, a viscoplastic solution was chosen, considering the creep effects. The Norton-Bayle creep law was used and the creep parameters were obtained from Samadi et al [9] and Teixeira et al [10]. The load was applied at $0.5 \mathrm{MPa} / \mathrm{min}$ and $0.3 \mathrm{MPa} / \mathrm{min}$ for the load levels of $5 \mathrm{MPa}$ and $3 \mathrm{MPa}$, respectively. After the load stage, 20 minutes of simulation were considered to analyse the evolution of the viscoplastic strains. Therefore, the total time considered for the analyses was 30 minutes.

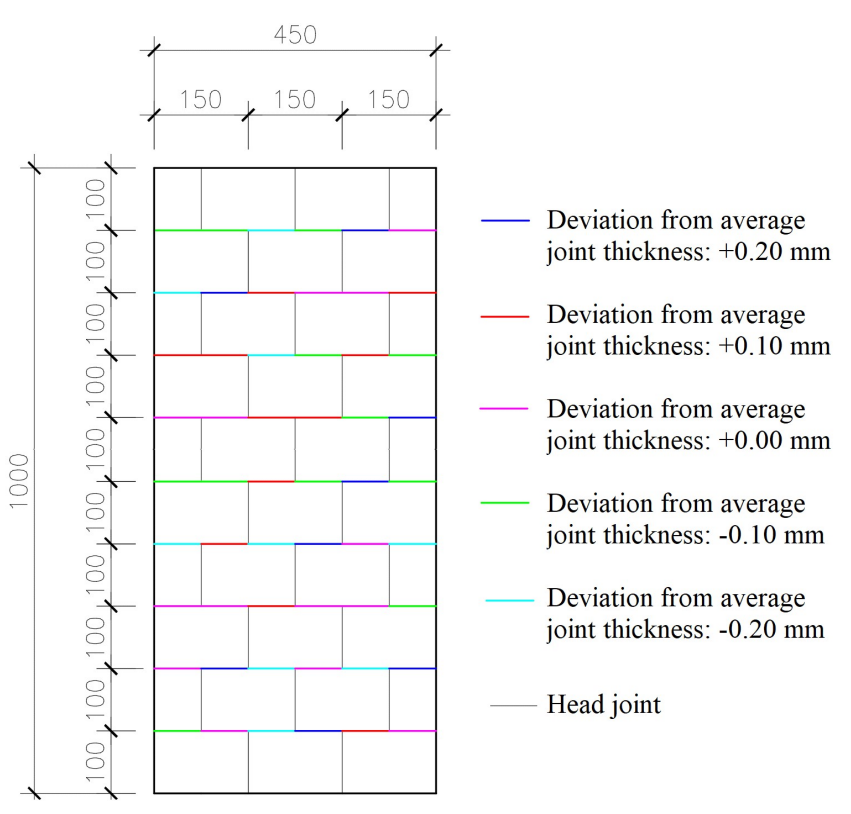

a)

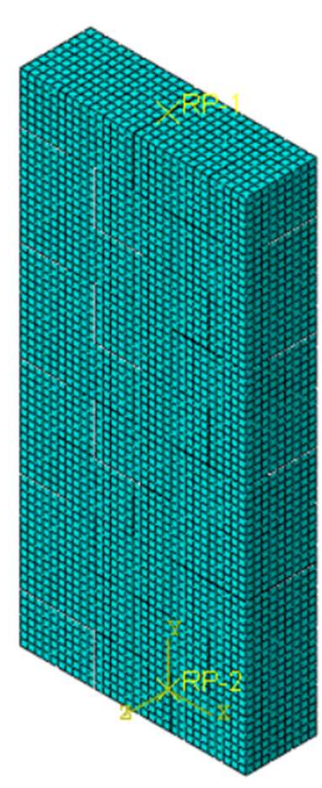

b)

Figure 12 - Specimens a) dimensions and joint thickness; b) Numerical model

\subsubsection{Results and discussions}

The numerical model was validated against experimental results of two compressive tests performed in masonry wallets at ambient temperature, as shown in Figure 13b. The numerical result is in good agreement with the experimental tests. The stresses developed in the specimen are presented in Figure 14 and Figure 15 for the loading levels of $3 \mathrm{MPa}$ and $5 \mathrm{MPa}$, respectively. The stresses were plot for $3 \mathrm{~min}, 5 \mathrm{~min}, 10 \mathrm{~min}$ and $30 \mathrm{~min}$. The loading level for each period is also indicated in the Figures, as its comparison to the bricks' compressive strength. For the simulations performed at ambient temperature, it is possible to identify significant stress concentrations in the wall caused by the geometrical imperfections. Based on the vertical stress distribution it is possible to identify the flow in 
Preprint version, Reference: Oliveira R, Rodrigues JP, Pereira JM, Lourenço PB, Marschall HU (2021), Normal and tangential behaviour of dry joints in refractory masonry. Engineering Structures, 243, 112600. https://doi.org/10.1016/j.engstruct.2021.112600

the loading path. As observed by Ngapeya [16], the failure of some bricks may be reached in spite the fact that the loading applied on the wall is far from the ultimate loading capacity of the brick.

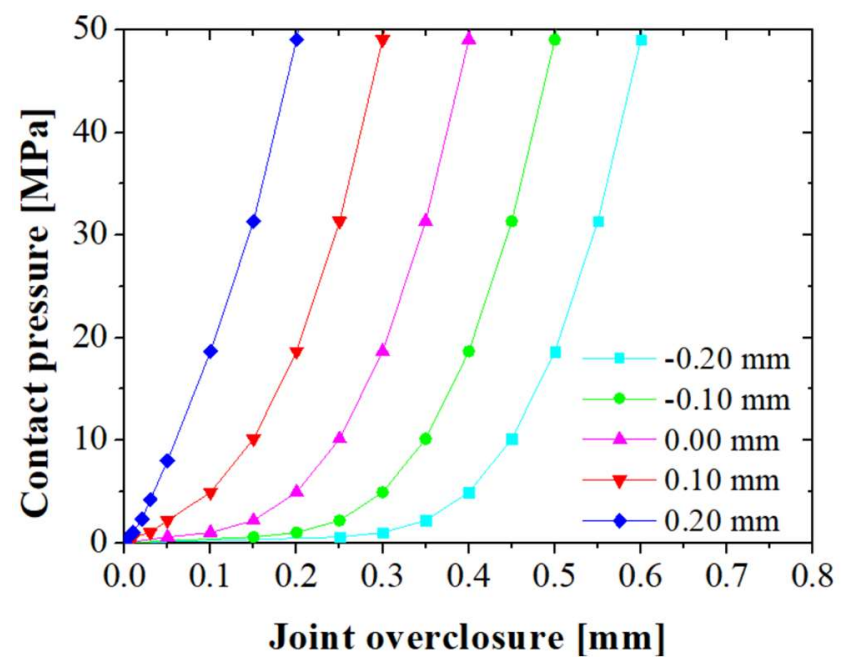

a)

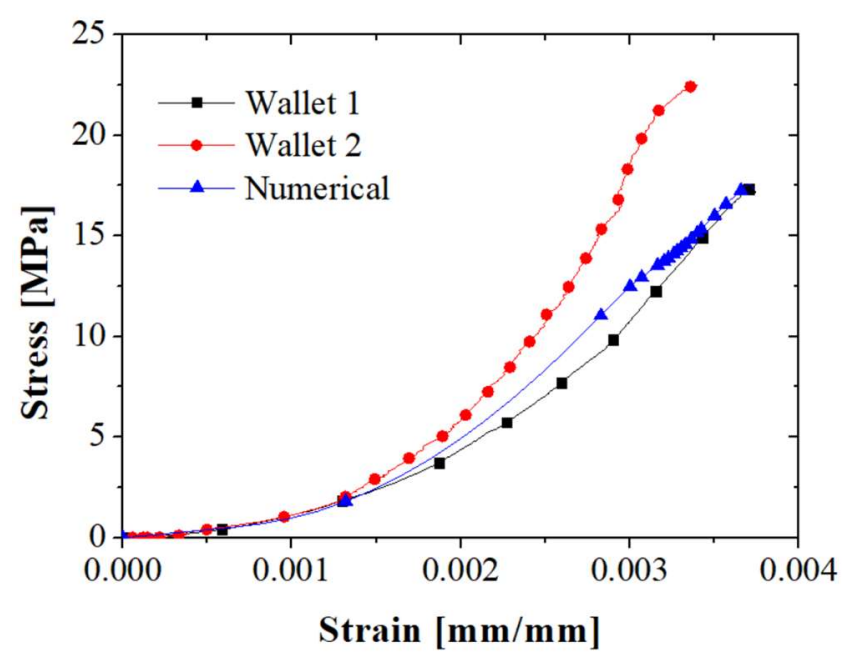

b)

Figure 13 - a) Joints pressure-overclosure relations b) Validation of the numerical model at ambient temperature 
Preprint version, Reference: Oliveira R, Rodrigues JP, Pereira JM, Lourenço PB, Marschall HU (2021), Normal and tangential behaviour of dry joints in refractory masonry. Engineering Structures, 243, 112600. https://doi.org/10.1016/j.engstruct.2021.112600

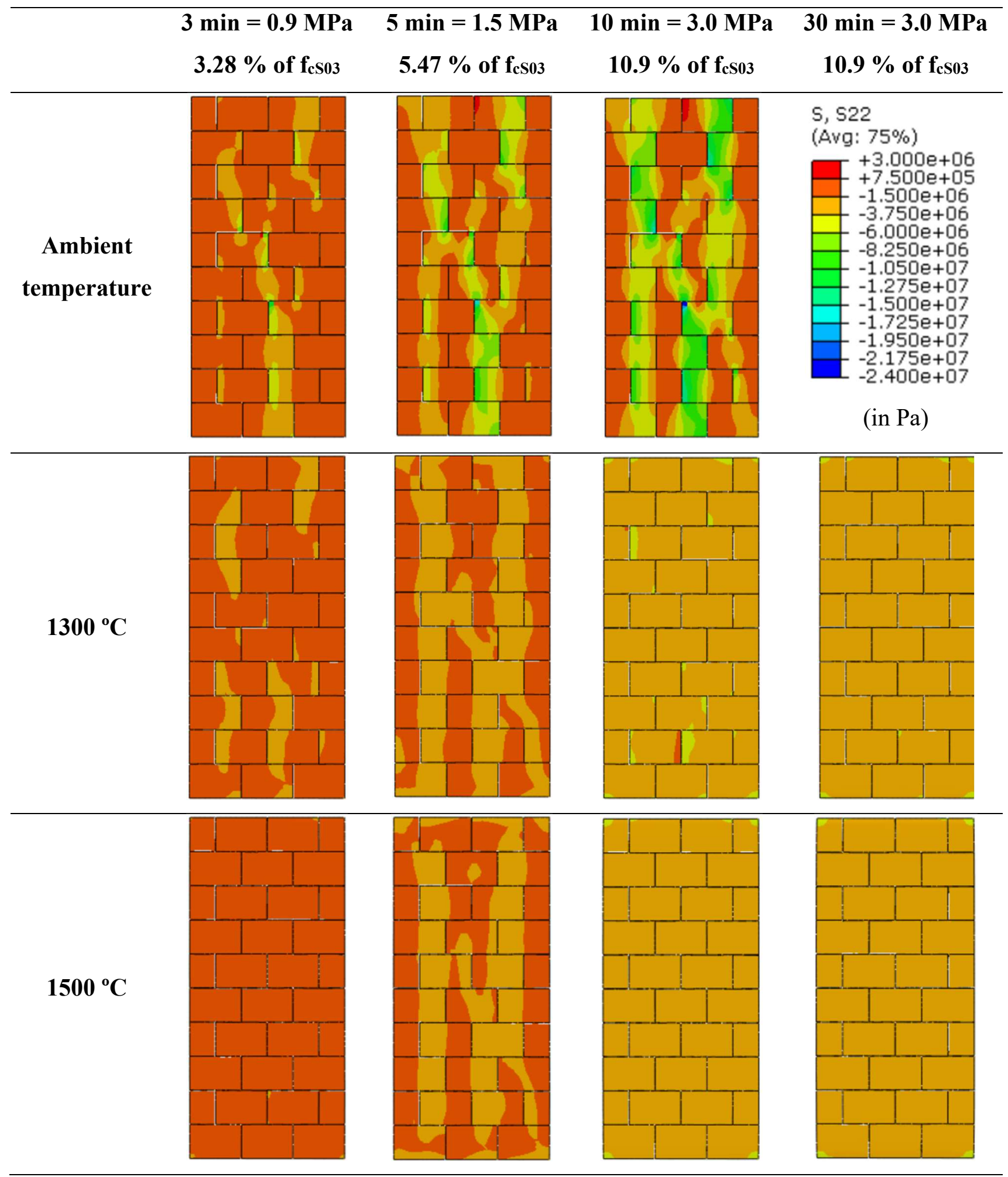

Figure 14 - Effects of brick's imperfections in height on the wall's behaviour at ambient temperature, $1300{ }^{\circ} \mathrm{C}$ and 1500 ${ }^{\circ} \mathrm{C}$ - Loading level of $3 \mathrm{MPa}$ 
Preprint version, Reference: Oliveira R, Rodrigues JP, Pereira JM, Lourenço PB, Marschall HU (2021), Normal and tangential behaviour of dry joints in refractory masonry. Engineering Structures, 243, 112600. https://doi.org/10.1016/j.engstruct.2021.112600

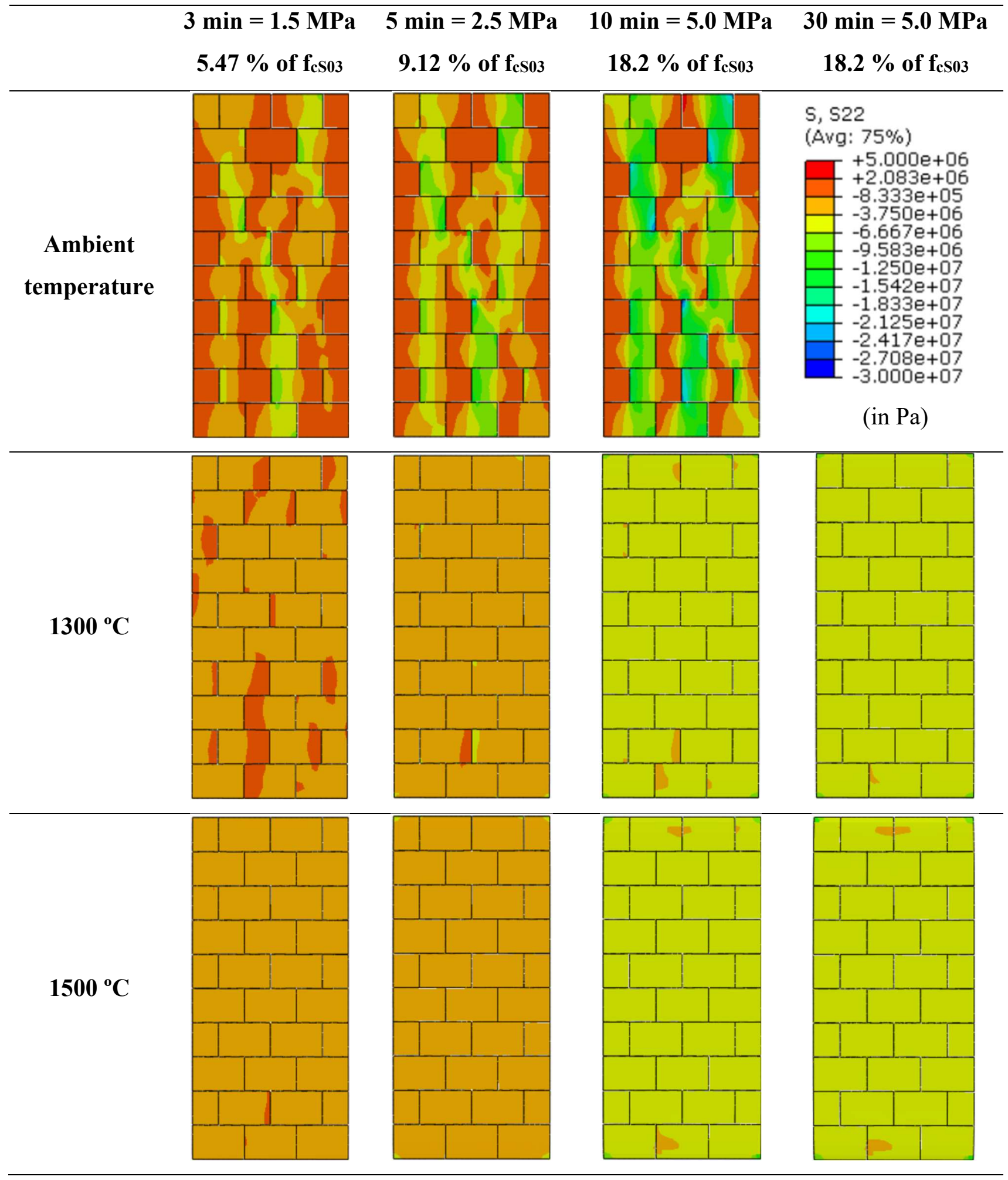

Figure 15 - Effects of the imperfections in height on the wall's behaviour at ambient temperature, $1300{ }^{\circ} \mathrm{C}$ and $1500{ }^{\circ} \mathrm{C}-$ Loading level of $5 \mathrm{MPa}$ 
Preprint version, Reference: Oliveira R, Rodrigues JP, Pereira JM, Lourenço PB, Marschall HU (2021), Normal and tangential behaviour of dry joints in refractory masonry. Engineering Structures, 243, 112600. https://doi.org/10.1016/j.engstruct.2021.112600

The simulations performed at high temperatures are subjected to creep. The viscoplastic strains occur with higher intensity in the areas where the stresses are higher, i.e., it is more significant along the loading path percolation. Due to this effect, the creep strains reduce the stress concentrations in the wall. The reduction is higher for the temperature of $1500^{\circ} \mathrm{C}$, as the creep strain rate increases with the temperature. The increasing of the load level from $3 \mathrm{MPa}$ to $5 \mathrm{MPa}$, also has an impact on reducing the stress concentrations, as the strain rate increases with the loading level. Therefore, due to the creep and the viscoplastic strains developing, the masonry joints closure, leading to a homogeneous stress distribution in the wall.

\subsection{Comparison between the bed and head joints under biaxial loads}

Aiming at evaluating the differences between the behaviour of the bed and head joints under biaxial loads, an inverse identification of the joint properties was performed, based on the experimental results provided by Prietl $[35,36]$. This author developed a dedicated device to test refractory wallets under biaxial compression (Figure 16) and performed tests at ambient and high temperatures. The results were used by other researches to calibrate and validate numerical models [4, 22, 23].

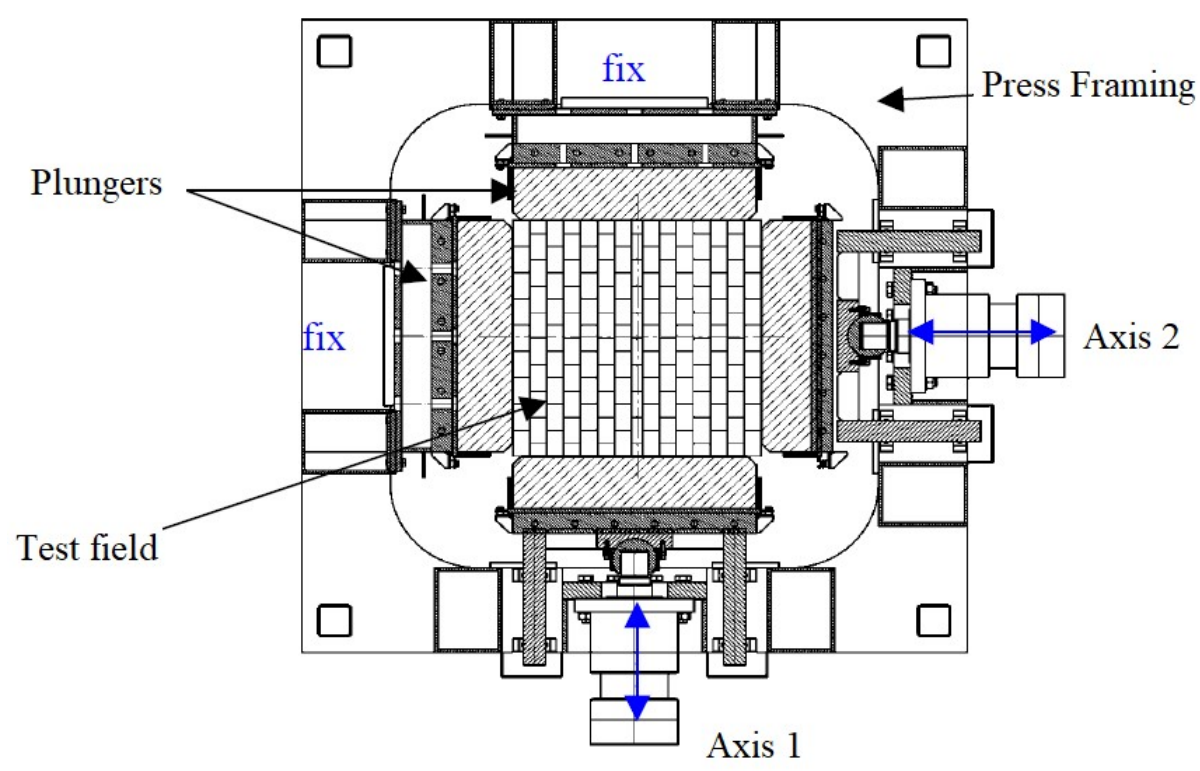

Figure 16 - Biaxial press: Experimental setup [35, 36] 
Preprint version, Reference: Oliveira R, Rodrigues JP, Pereira JM, Lourenço PB, Marschall HU (2021), Normal and tangential behaviour of dry joints in refractory masonry. Engineering Structures, 243, 112600. https://doi.org/10.1016/j.engstruct.2021.112600

\subsubsection{Numerical model}

The numerical analysis presented in this section have been again performed using the finite element software Abaqus [37]. The geometry model was based on the experimental setup adopted by Prietl, in 2009, [35-36] (Figure 16). A detailed micro-modelling strategy was adopted, in which the bricks are represented by continuous elements and the dry joint interfaces are represented by surface-to-surface contacts. The masonry wall was discretized with 8-node solid elements (C3D8R elements), the final mesh was generated automatically by Abaqus software and was rather refined, 121708 elements and 231844 nodes were used (Figure 17). The Concrete Damage Plasticity (CDP) model was used to represent the magnesia-chromite bricks. Table 6 presents the strength properties adopted in the numerical model, while the rest of the properties are the same as in Table 4.

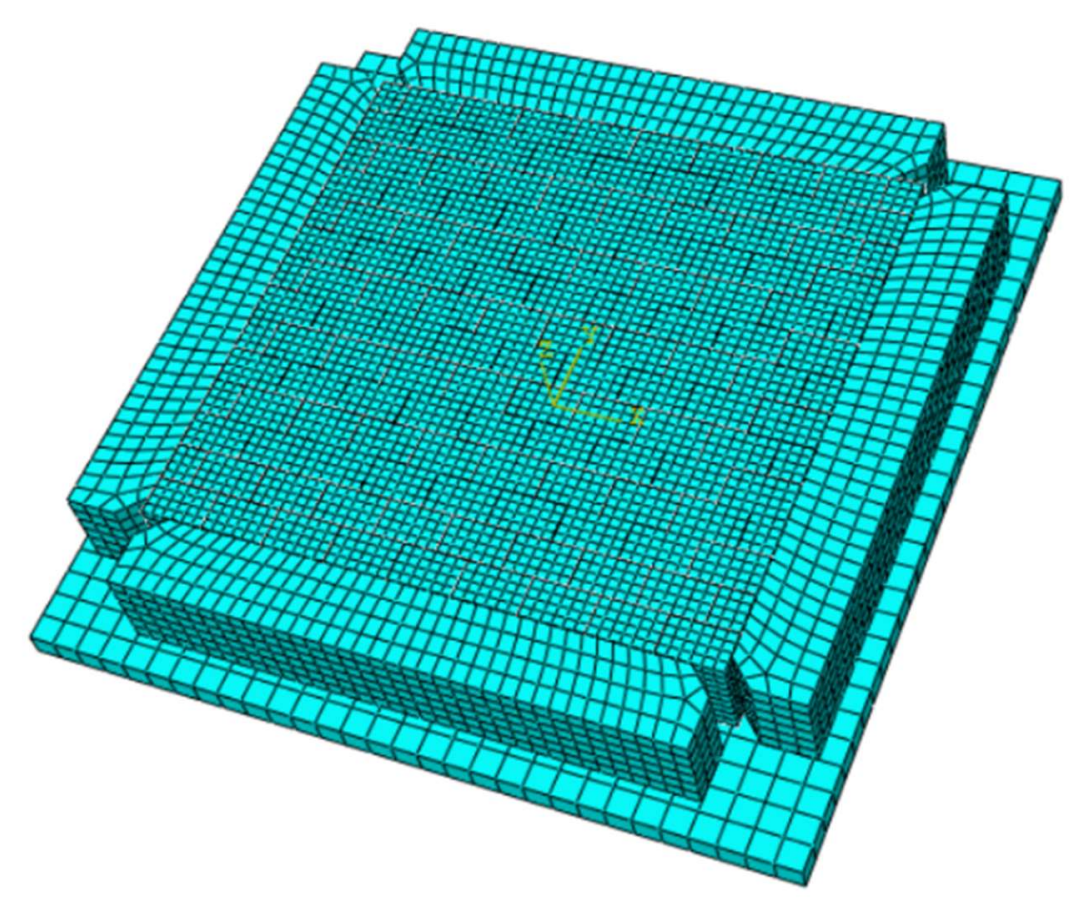

Figure 17 - Numerical model: mesh

Table 6 - Strength parameters of the magnesia chromite bricks

\begin{tabular}{cc}
\hline $\boldsymbol{f}_{\boldsymbol{c}}[\mathrm{MPa}]$ & 105.0 \\
\hline $\boldsymbol{f}_{\boldsymbol{t}}[\mathbf{M P a}]$ & 7.76 \\
\hline $\boldsymbol{G}_{\boldsymbol{f}}\left[\mathbf{J} / \mathbf{m}^{2}\right]$ & 131.1 \\
\hline
\end{tabular}


Preprint version, Reference: Oliveira R, Rodrigues JP, Pereira JM, Lourenço PB, Marschall HU (2021), Normal and tangential behaviour of dry joints in refractory masonry. Engineering Structures, 243, 112600. https://doi.org/10.1016/j.engstruct.2021.112600

\subsubsection{Results and discussions}

The inverse identification of the joint parameters was performed using the experimental results (Figure 18a). Based on the inverse identification, it was possible to generate the joint closure curves for bed and head joints (Figure 18b), based on the equation proposed by Thanoon et al [12]. The head joints present a stiffer behaviour than the bed joints. This is mostly likely because the head joints are formed by one brick in contact with another brick, while the bed joints are formed by one brick in contact with two other bricks. Consequently, in the latter case, the imperfections of multiple bricks aligned in a masonry course affect more strongly the joint behaviour and results in a joint with a higher compressibility and a lower stiffness.

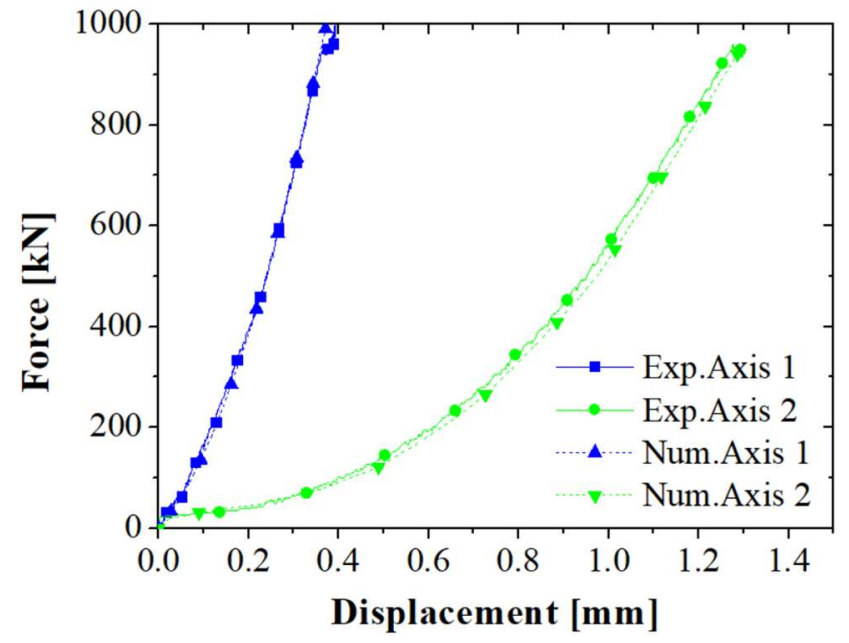

a)

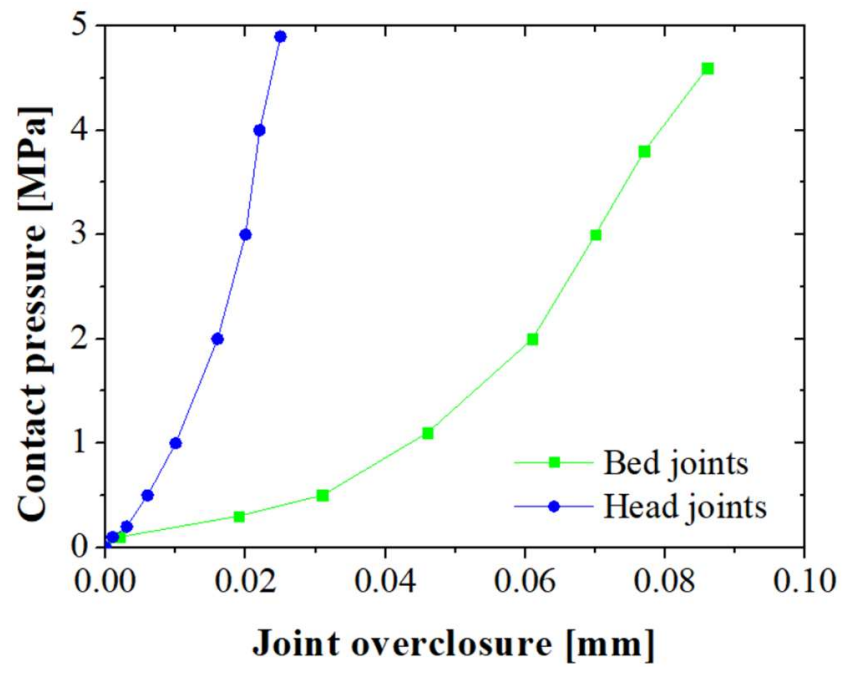

b)

Figure 18 - Results for biaxial press: a) Full load displacement measured and simulated diagram; b) Obtained joint closure relations for head and bed joints

Figure 19 shows the displacement distribution for different loading levels. It is clear that the displacements in the direction orthogonal to the bed joints are higher, as the number of joints in this direction is higher and these joints present higher compressibility. Moreover, it is possible to identify that a significant part of the displacements is related to joint closure process, as high displacements are obtained for small loading levels (Figure $19 \mathrm{a}$ and b). This is confirmed by the experimental results. 
Preprint version, Reference: Oliveira R, Rodrigues JP, Pereira JM, Lourenço PB, Marschall HU (2021), Normal and tangential behaviour of dry joints in refractory masonry. Engineering Structures, 243, 112600. https://doi.org/10.1016/j.engstruct.2021.112600
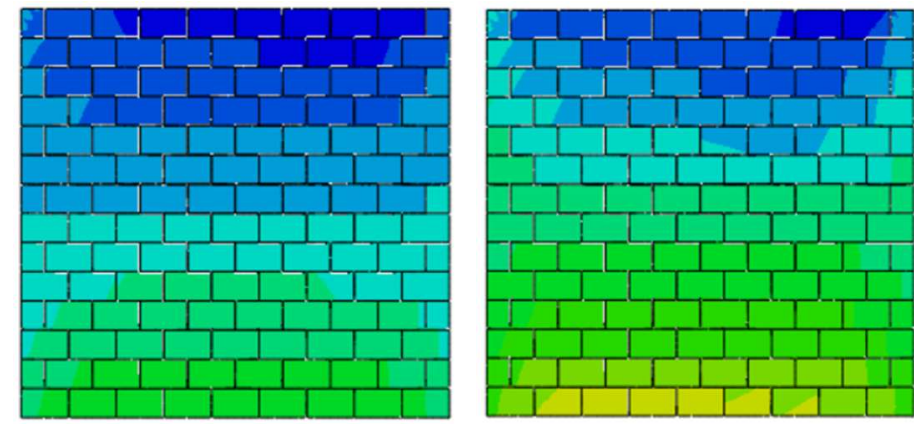

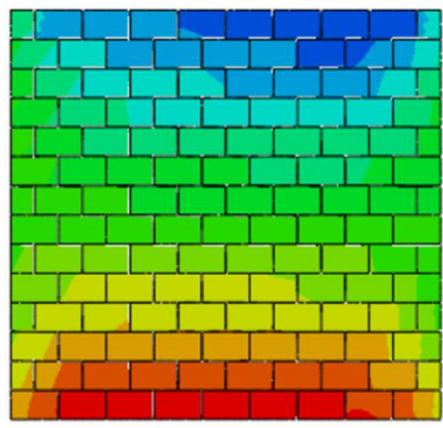

U, Magnitude

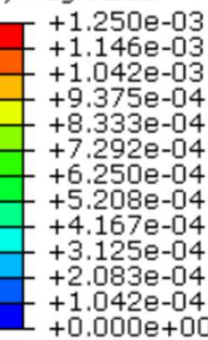

(in $\mathrm{m}$ ) b)

a)

Figure 19 - Displacement fields at ambient temperature for different loading levels: a) 25\%, b) 50\%, c) 100\%

Nguyen et al [4] and Ali et al [23] have performed numerical simulations of the same experiment using homogenization techniques. The numerical predictions of the authors presented good agreement with the experimental results. Therefore, the micro modelling and the homogenization techniques are suitable to represented the behaviour of dry-stacked refractory masonry.

\section{Joint tangential behaviour tests}

In this study, a special device was developed to evaluate the friction angle of dry joints at ambient and high temperatures, based on the test described by Gasser et al [3]. A tilting beam is positioned inside an electrical furnace in a pinned support, while a hydraulic jack connected to the beam by a load rod was used to increase the rotation of the beam. Two stacked bricks were positioned on the device, the bottom brick was constrained by steel plates, but the upper brick was allowed to move (Figure 20a). When the hydraulic jack went upward, it increased the inclination of the beam, from zero degrees up to the friction angle of the bricks (Figure 20b). The specimens consisted of two stacked bricks of type $\mathrm{B}$, therefore the final dimensions of the prism were $250 \times 124 \mathrm{~mm}$ by $152 \mathrm{~mm}$ in height [42].

A photo of the experimental setup is presented in Figure 21. A W+B servo controlled hydraulic unit was used to control the hydraulic jack that applied the load. The data was acquired using a TML TDS601 Datalogger. In order to control the temperatures in the inclinable beam and hydraulic jack, ceramic wool was used to protect the steel components from high temperatures. Moreover, a cooling device was used to cool the load rod, avoiding excessive temperatures in the hydraulic jack. 
Preprint version, Reference: Oliveira R, Rodrigues JP, Pereira JM, Lourenço PB, Marschall HU (2021), Normal and tangential behaviour of dry joints in refractory masonry. Engineering Structures, 243, 112600. https://doi.org/10.1016/j.engstruct.2021.112600

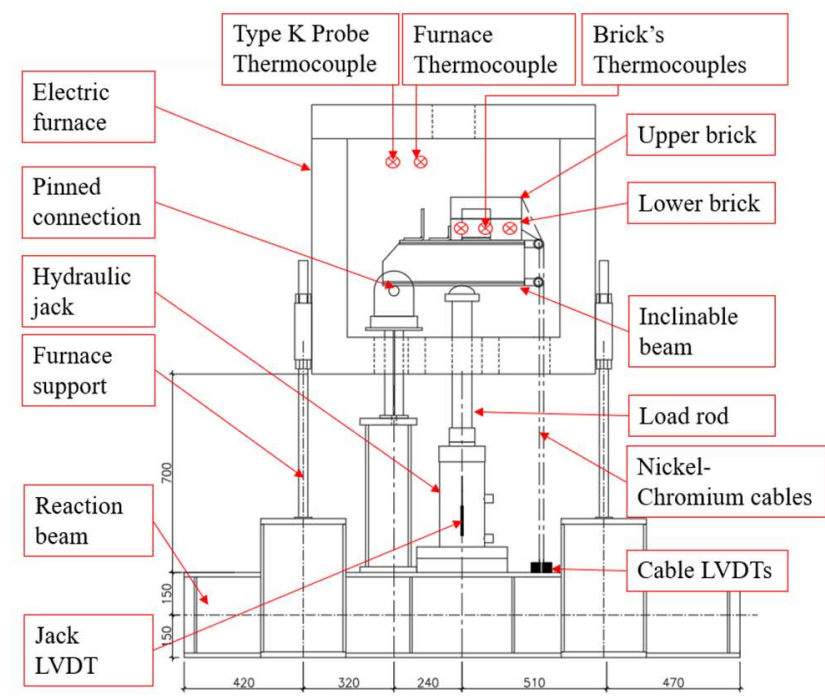

a)

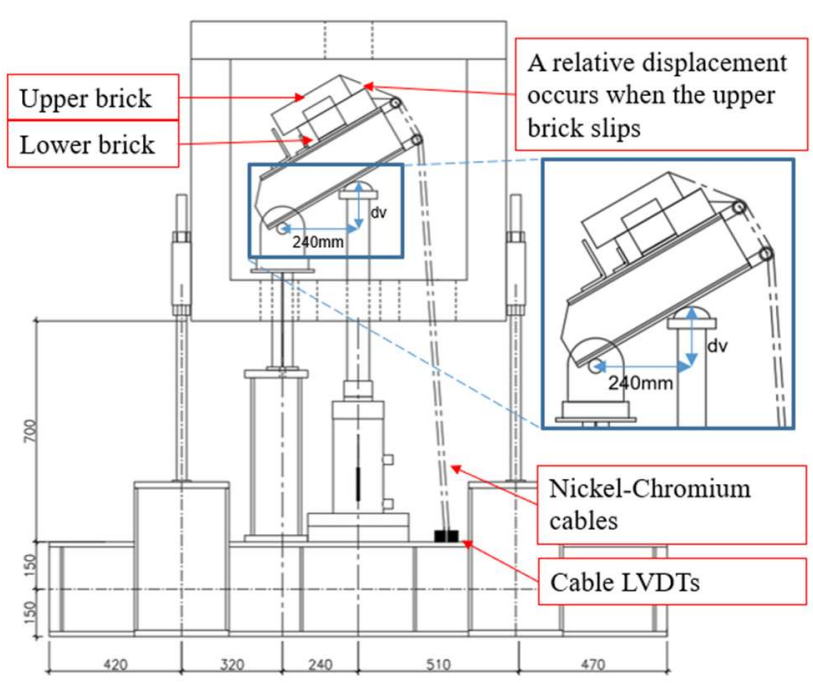

b)

Figure 20 - Slip test scheme: a) before slipping, b) after slipping;

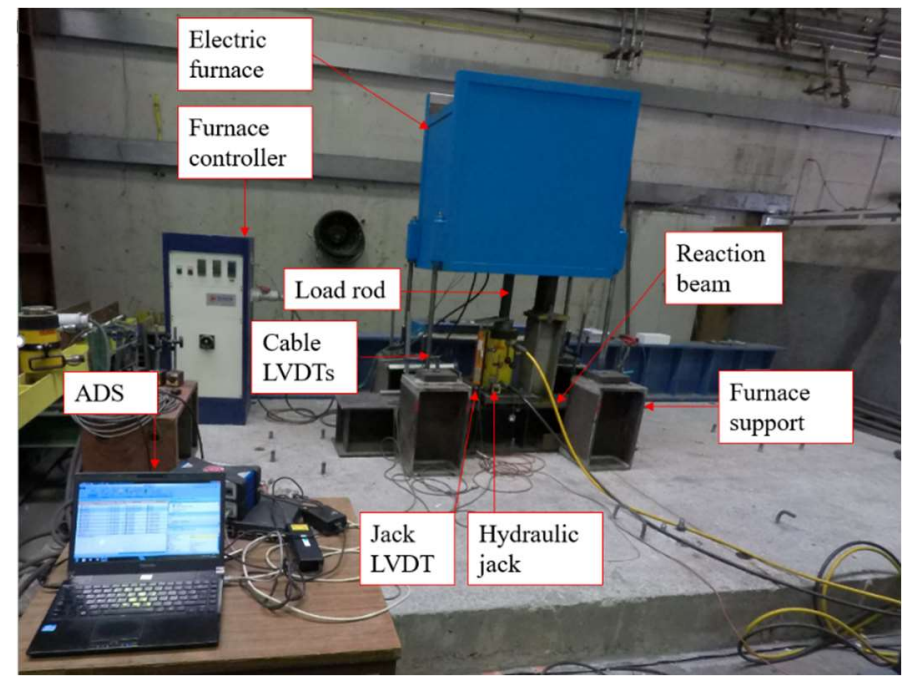

Figure 21 - General view of the slip test experimental set-up

\subsection{Test instrumentation}

Two cable LVDTs were used to measure the displacement of the bottom brick and one cable LVDT was used to monitor the displacement of the upper brick. The LVDTs were connected to the bricks using Nickel-Chromium cables in order to avoid the influence of their thermal elongation. When the upper brick slips, a differential displacement between these LVDTs was observed. A rod LVDT was used to measure the displacement of the hydraulic jack. The friction angle ( $\varnothing)$ between the bricks may 
Preprint version, Reference: Oliveira R, Rodrigues JP, Pereira JM, Lourenço PB, Marschall HU (2021), Normal and tangential behaviour of dry joints in refractory masonry. Engineering Structures, 243, 112600. https://doi.org/10.1016/j.engstruct.2021.112600

be calculated by the arctangent of the vertical displacement measured at the jack $\left(d_{v}\right)$ divided by the offset between the axis of the jack and the axis of the hinge (Figure 20b), as shown in Eq. 3:

$$
\varnothing=\operatorname{atan}\left(d_{v} / 240 m m\right)
$$

The furnace had a type $\mathrm{K}$ thermocouple that was used to control the temperature. A type $\mathrm{K}$ probe thermocouple was used to record the temperatures in the furnace during the test. Additionally, three type $\mathrm{K}$ wire thermocouples were used to measure the temperatures inside the bottom brick (Figure 20).

\subsection{Test procedure}

The experimental procedure had the following steps: $i$ ) The bricks were placed at the inclinable beam and the instrumentation was installed; $i$ ) The furnace was set to heat at $10^{\circ} \mathrm{C} / \mathrm{min}$. Once the temperature test was reached, a dwell time of $1.5 \mathrm{~h}$ was applied; iii) The hydraulic jack was set to move upward at a rate of $0.5 \mathrm{~mm} / \mathrm{s}$, up to the maximum of $170 \mathrm{~mm} ; i v$ ) When the friction angle is reached, the upper brick slips. Cables LVDT's were used to control the differential displacement between the upper and bottom brick; v) The friction angle was calculated based on the displacement of the hydraulic jack and the offset between the hinge axis and the hydraulic jack axis, as shown in Eq. 3.

In order to confirm that the temperature was homogenized within the specimen, the bottom brick had thermocouples. Figure 22 shows the position of the thermocouples installed in the specimens and the development of temperature. It is clear that at the time of the application of the mechanical load that the specimen was under homogeneous temperature.

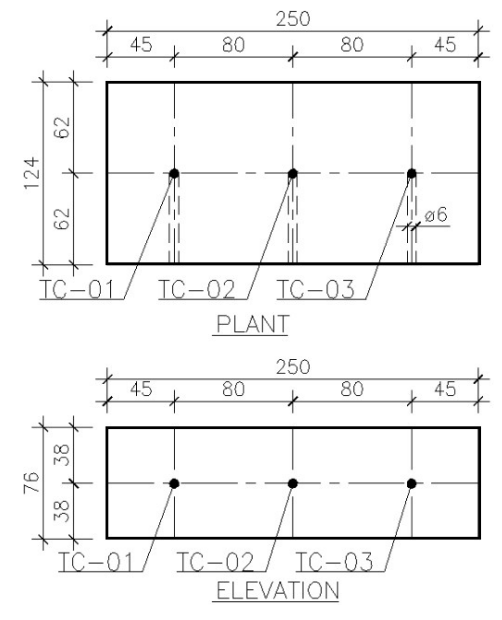

a)

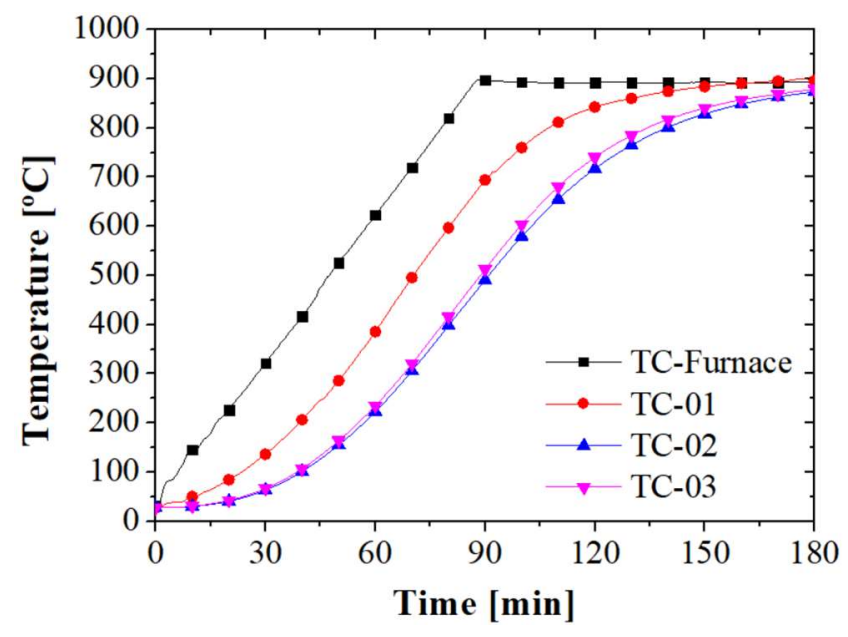

b)

Figure 22 - a) Thermocouples position, b) Temperature evolution for the slip tests at $900^{\circ} \mathrm{C}$ 
Preprint version, Reference: Oliveira R, Rodrigues JP, Pereira JM, Lourenço PB, Marschall HU (2021), Normal and tangential behaviour of dry joints in refractory masonry. Engineering Structures, 243, 112600. https://doi.org/10.1016/j.engstruct.2021.112600

\subsection{Test results and discussions}

Figure 23 shows the displacement curves for the different temperatures. The curves of the graphs are from the results of the first specimen among the tests carried, six for ambient temperature and three for the other temperature levels tested. These displacements were measured in the hydraulic jack (jack's LVDT) and the brick (cable's LVDT) (see Fig. 25 for references).

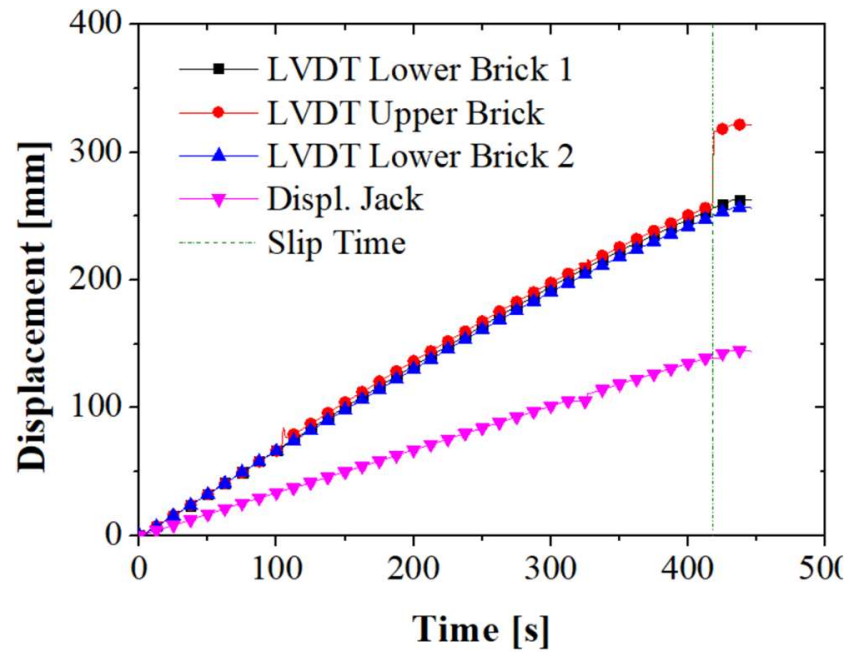

a)

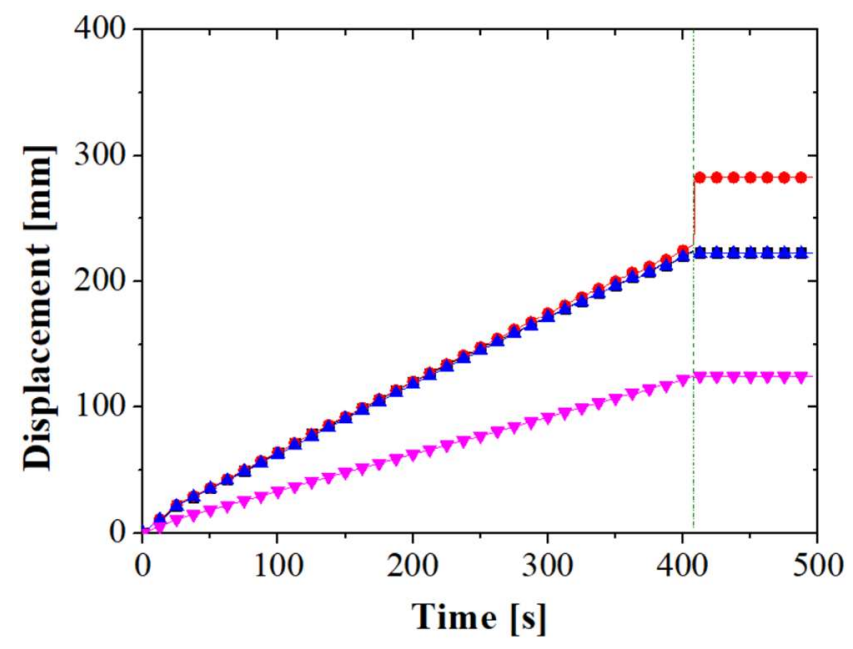

c)

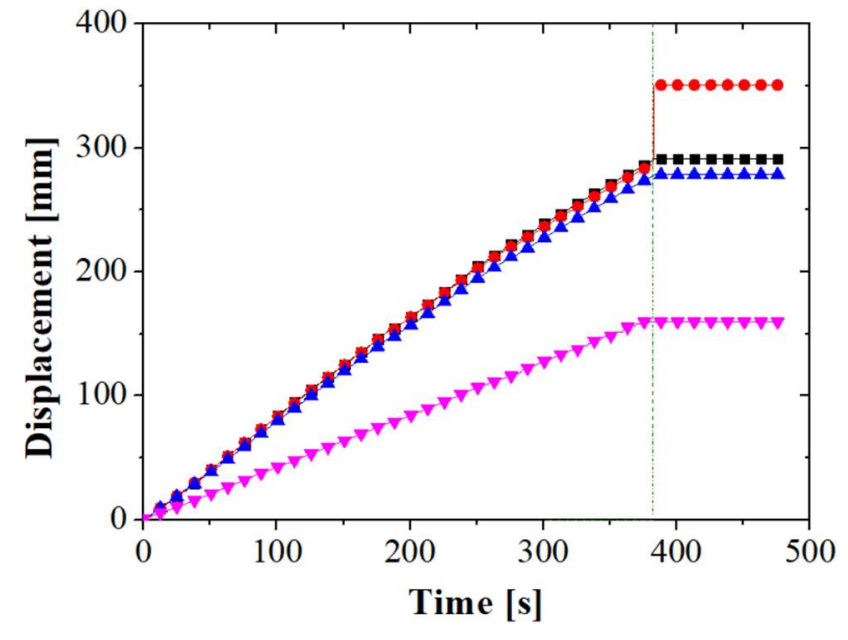

b)

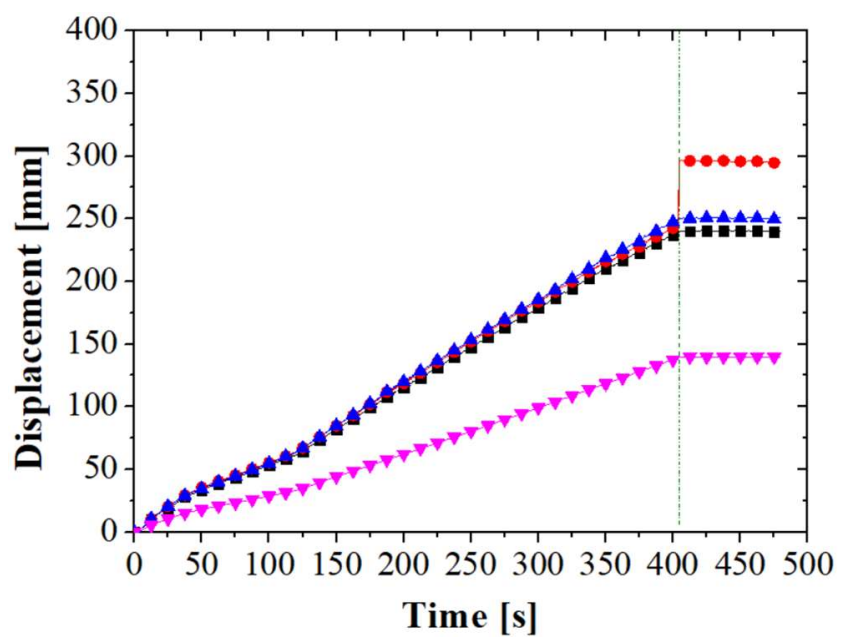

d)

Figure 23 - Displacements a) ambient temperature; b) $300^{\circ} \mathrm{C}$; c) $600^{\circ} \mathrm{C}$; d) $900{ }^{\circ} \mathrm{C}$

The slip test results for ambient temperature, $300^{\circ} \mathrm{C}, 600^{\circ} \mathrm{C}$ and $900^{\circ} \mathrm{C}$ are presented in Table 7. The friction angle $(\varnothing)$ and friction coefficient $(\mu)$ and the standard deviations are also presented. 
Preprint version, Reference: Oliveira R, Rodrigues JP, Pereira JM, Lourenço PB, Marschall HU (2021), Normal and tangential behaviour of dry joints in refractory masonry. Engineering Structures, 243, 112600. https://doi.org/10.1016/j.engstruct.2021.112600

Table 7 - Results of the slip tests at ambient and high temperatures

\begin{tabular}{|c|c|c|c|c|c|c|c|c|c|c|}
\hline $\begin{array}{c}\text { Test } \\
\text { series }\end{array}$ & Temperature & Specimen & $\begin{array}{c}\text { Hydraulic } \\
\text { jack } \\
\text { displacement } \\
\text { [mm] }\end{array}$ & $\begin{array}{c}\text { Horizontal } \\
\text { offset } \\
\text { [mm] }\end{array}$ & {$\left[{ }^{\circ}\right]$} & {$[-]$} & $\boldsymbol{\sigma}_{\text {avg }}$ & $\sigma(\boldsymbol{\theta})$ & $\mu_{\text {avg }}$ & $\sigma(\mu)$ \\
\hline \multirow{6}{*}{ ST.RT } & \multirow{6}{*}{$20{ }^{\circ} \mathrm{C}$} & $\begin{array}{l}\text { ST.RT.01A } \\
\text {. }\end{array}$ & 138.9 & 240.0 & 30.06 & 0.58 & \multirow{6}{*}{30.9} & \multirow{6}{*}{0.78} & \multirow{6}{*}{0.598} & \multirow{6}{*}{0.02} \\
\hline & & ST.RT.01B & 143.6 & 240.0 & 30.89 & 0.60 & & & & \\
\hline & & ST.RT.01C & 147.8 & 240.0 & 31.63 & 0.62 & & & & \\
\hline & & ST.RT.02A & 139.1 & 240.0 & 30.10 & 0.58 & & & & \\
\hline & & ST.RT.02B & 146.6 & 240.0 & 31.42 & 0.61 & & & & \\
\hline & & ST.RT.02C & 135.5 & 240.0 & 29.45 & 0.56 & & & & \\
\hline \multirow{3}{*}{ ST.300 } & \multirow{3}{*}{$300^{\circ} \mathrm{C}$} & ST.300.01 & 119.1 & 240.0 & 26.39 & 0.50 & \multirow{3}{*}{26.5} & \multirow{3}{*}{0.49} & \multirow{3}{*}{0.498} & \multirow{3}{*}{0.01} \\
\hline & & ST.300.02 & 122.8 & 240.0 & 27.10 & 0.51 & & & & \\
\hline & & ST.300.03 & 116.6 & 240.0 & 25.91 & 0.49 & & & & \\
\hline \multirow{3}{*}{ ST.600 } & \multirow{3}{*}{$600^{\circ} \mathrm{C}$} & ST.600.01 & 124.8 & 240.0 & 27.47 & 0.52 & \multirow{3}{*}{27.0} & \multirow{3}{*}{0.55} & \multirow{3}{*}{0.510} & \multirow{3}{*}{0.01} \\
\hline & & ST.600.02 & 118.4 & 240.0 & 26.26 & 0.49 & & & & \\
\hline & & ST.600.03 & 124.2 & 240.0 & 27.36 & 0.52 & & & & \\
\hline \multirow{3}{*}{ ST.900 } & \multirow{3}{*}{$900^{\circ} \mathrm{C}$} & ST.900.01 & 133.4 & 240.0 & 29.07 & 0.56 & \multirow{3}{*}{27.9} & \multirow{3}{*}{1.17} & \multirow{3}{*}{0.530} & \multirow{3}{*}{0.03} \\
\hline & & ST.900.02 & 129.4 & 240.0 & 28.33 & 0.54 & & & & \\
\hline & & ST.900.03 & 118.6 & 240.0 & 26.30 & 0.49 & & & & \\
\hline
\end{tabular}

The average friction angle at ambient temperature is $30.9^{\circ}$. The friction angle was $26.5^{\circ}$ at $300^{\circ} \mathrm{C}$ that is below the value at ambient temperature. However, a small increasing observed when comparing with the value at $300^{\circ} \mathrm{C}$, being $27.0^{\circ}$ for $600^{\circ} \mathrm{C}$ and $27.9^{\circ}$ for $900^{\circ} \mathrm{C}$ (Figure 24). The reduction of the friction coefficients when compared to the ambient temperature results were $14.2 \%, 12.6 \%$ and $9.7 \%$ for the temperatures of $300^{\circ} \mathrm{C}, 600^{\circ} \mathrm{C}$ and $900^{\circ} \mathrm{C}$, respectively. A small standard deviation was found for all test series. 


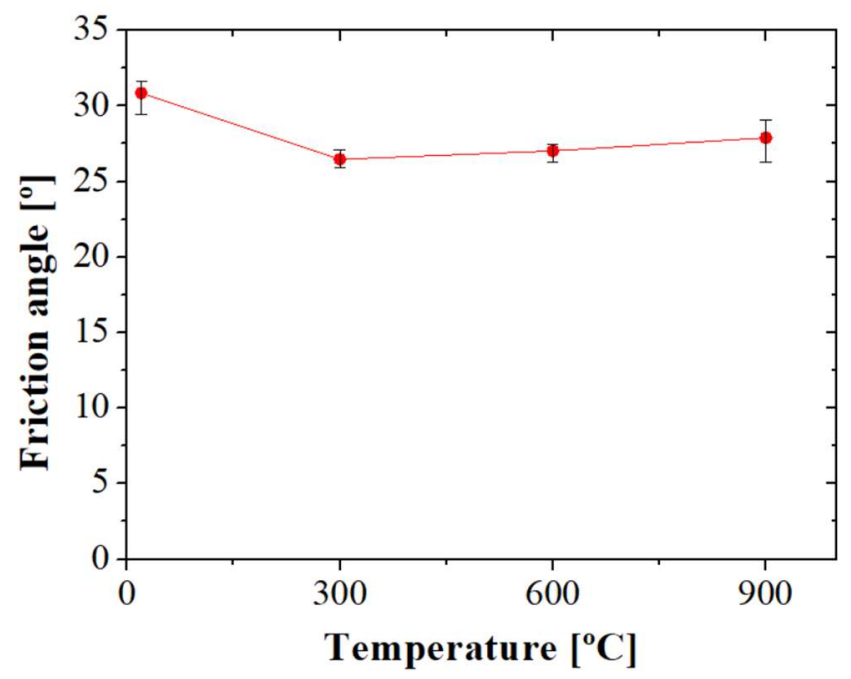

Figure 24 - Evolution of the friction angle with the temperature

\section{Conclusions}

In the present work, an analysis of the thermomechanical behaviour of dry joints in refractory masonry has been carried out, both at experimental and numerical level. The compressive strength at ambient and high temperatures of the bricks were also assessed. A statistical analysis of the distribution of the brick shape imperfections was carried out. Experimental and numerical studies were performed for analysing the normal behaviour of dry joints: a classical joint closure test was presented, the bed joint closing states were measured for a masonry wallet using DIC, the effects of brick imperfections in height on the mechanical properties of the brick and of the wall at ambient and high temperatures were determined and a comparison between the bed and head joints behaviour was presented. The joint tangential behaviour was analysed and a tailored test device was developed for evaluating the friction coefficient between the bricks at ambient and high temperatures.

The following conclusions maybe drawn from this study:

- Refractory bricks exhibited anisotropic behaviour and mould dependent characteristics. The tested specimens presented different compressive strength $\left(f_{c}\right)$, ultimate compressive strain $\left(\varepsilon_{c u}\right)$ and Young's modulus $(E)$. These differences were found for different shapes of the bricks and for different directions in the same brick. The anisotropic behaviour of the material and the mould dependent mechanical parameters are caused by the pressing and the firing procedure. $\boldsymbol{f}_{\text {c avg }}$ of brick A tested in the pressing direction (series S01) was 29.2 MPa. $\boldsymbol{f}_{\boldsymbol{c} \text { avg }}$ of brick B tested 
in the pressing direction (series S02) and orthogonal to the pressing direction (series S03) were 32.4 MPa and 27.4 MPa, respectively. $\boldsymbol{f}_{\text {c avg }}$ of series S04 are 24.2MPa, 34.4 MPa and 27.0 MPa for the temperatures of $600^{\circ} \mathrm{C}, 800^{\circ} \mathrm{C}$ and $1.000^{\circ} \mathrm{C}$, respectively.

- The brick shape imperfections followed a Gaussian distribution. The imperfections were found to be smaller (from $-1.1 \mathrm{~mm}$ up to $+0.8 \mathrm{~mm}$ ) and with a small standard deviation $(\sigma=0.41 \mathrm{~mm})$ in the directions orthogonal to pressing. In the direction of pressing, higher imperfections (from - $2.4 \mathrm{~mm}$ up to $+1.4 \mathrm{~mm})$ and a higher deviation $(\sigma=0.84 \mathrm{~mm})$ were observed. In the pressing direction, the dimensions of the brick were influenced by the pressing procedure and by the amount of material injected in the moulds, whereas in the orthogonal direction mostly the firing played a role.

- A classical joint closure test was performed in two stacked bricks and compared to joint closure measurements on a refractory wallet measured by DIC. It was observed that the heterogeneity on the joint closure was higher in the masonry wallet. In the latter case, the geometric imperfections in a full course have influence the contact conditions of the bricks, resulting in joints with higher heterogeneity and compressibility.

- The effects of brick imperfections in height on the loadbearing capacity of the brick itself was evaluated. The five original loading cases were expanded to seven loading cases aiming to take into account banana shaped bricks. The load bearing capacity was determined for each loading case and also the expected crack pattern. The crack paths predicted numerically were able to replicate the cracks observed in dry-stacked masonry wallets.

- The influence of the brick imperfections in height on the behaviour of masonry walls was studied numerically. Two loading levels (3 MPa and $5 \mathrm{MPa}$ ) and three temperatures (ambient temperature, $1300{ }^{\circ} \mathrm{C}$ and $1500{ }^{\circ} \mathrm{C}$ ) were considered. The brick imperfections were randomly considered in the wall following the statistical distribution obtained in the present research. For the ambient temperature models, the imperfections resulted in stress concentrations and in a non-homogeneous flow of forces through the wall. For the high temperature models, the viscoplastic effects led to reductions in stress concentrations. It was observed that higher temperatures and higher loading levels results in a more homogeneous stress distribution, as the creep strain rate is increased.

- An inverse identification of the bed and head joints pressure-overclosure curves was performed based on the experimental results available on the literature. It was observed that the head joints 
present a stiffer behaviour when compared to the bed joints and smaller compressibility, mostly likely because they are formed by one brick in contact with one brick, while the bed joints reflect the irregularity of multiple bricks. Consequently, in the latter case the imperfections have larger influence on the joint behaviour, resulting in a thicker joint.

- A newly test setup for evaluating the friction coefficient between bricks in dry joints was developed. A reduction of the friction coefficient was found in function of the temperature increasing. The average friction angle at ambient temperature is $30.9^{\circ}$. The friction angle was $26.5^{\circ}$ at $300^{\circ} \mathrm{C}$ that is below the value at ambient temperature. However, a small increasing observed when comparing with the value at $300^{\circ} \mathrm{C}$, being $27.0^{\circ}$ for $600^{\circ} \mathrm{C}$ and $27.9^{\circ}$ for $900^{\circ} \mathrm{C}$.

The results presented in this study may be used for development and validation of numerical models, to simulate the behaviour of refractory linings. However, the effects of the uneven stress distribution and the effects of thermal cycles in the joints behaviour was not evaluated, consequently, the authors recommend these topics for future researches. Moreover, experimental campaigns in masonry wallets are still necessary to evaluate the structure effects on masonry wallets under uniaxial and biaxial conditions.

\section{Acknowledgements}

The authors would like to thank the support of European Commission under the framework of Marie Skłodowska-Curie Actions Innovative Training Networks, project ATHOR - Advanced THermomechanical multiscale mOdelling of Refractory linings 764987 Grant.

\section{Conflicts of Interest}

The authors declare no conflict of interest. 
Preprint version, Reference: Oliveira R, Rodrigues JP, Pereira JM, Lourenço PB, Marschall HU (2021), Normal and tangential behaviour of dry joints in refractory masonry. Engineering Structures, 243, 112600. https://doi.org/10.1016/j.engstruct.2021.112600

\section{References}

[1] Allaoui, S.; Rekik, A.; Gasser, A., Blond, E.: Andreev, K. "Digital Image Correlation measurements of mortarless joint closure in refractory masonries". Construction and Building Materials, vol. 162, 2018, pp. 334-344

[2] J. Poirier and M. Rigaud. "Corrosion of Refractories: The Fundamentals". F.I.R.E Compendium Series. 2017, 450 pages

[3] Gasser, A.; Terny-Rebeyrotte, K.; Boisse, P. "Modelling of joint effects on refractory lining behaviour”. Journal of Materials: Design and Applications, vol. 218, issue 1, 2004, pp.19-28.

[4] Nguyen, T.; Blond, E.; Gasser, A.; Prietl; T. "Mechanical homogenisation of masonry wall without mortar”. European Journal of Mechanics - A/Solids. vol. 28, Issue 3, 2009, pp. 535-544.

[5] Shubin, V. "Mechanical effects on the lining of rotary cement kilns" Refractories and Industrial Ceramics, vol. 42, no 5-6, 2001, pp. 245-250.

[6] Ramanenka, D.; Stjernberg, J.; Eriksson, K.; Jonsén, P. "Modeling of refractory brick furniture in rotary-kiln using finite element approach". $11^{\text {th }}$ World Congress on Computational Mechanics (WCCM XI), Barcelona - Spain, 2014, pp. 1199-1210

[7] Khlifi, I. "Optimisation of optical methods for strain field measurements dedicated to the characterisation of the fracture behaviour of refractories: Application to magnesia based materials. Material chemistry". PhD Thesis, University of Limoges, 2019, 182 pages

[8] Stueckelschweiger, M.; Gruber, D.; Jin, S.; Harmuth, H. "Creep testing of carbon containing refractories under reducing conditions”. Ceramics International, vol. 45, Issue 8, 2019, pp. 9776-9781 [9] Samadi, S.; Jin, S.; Gruber, D.; Harmuth, H.; Schachneret, S. "Statistical study of compressive creep parameters of an alumina spinel refractory". Ceramics International, vol. 46, Issue 10-A, 2020, pp. $14662-14668$

[10] Teixeira, L.; Samadi, S.; Gillibert, J.; Jin S.; Sayet, T.; Gruber, D.; Blond, E. "Experimental Investigation of the Tension and Compression Creep Behavior of Alumina-Spinel Refractories at High Temperatures". Ceramics, vol.3(3), 2020, pp. 372-383

[11] Andreev, K.; Sinnema, S.; Rekik, A.; Allaoui, S.; Blond, E.; Gasser, A. "Compressive behaviour of dry joints in refractory ceramic masonry". Construction and Building Materials, vol. 34, 2012, pp. 402-408 
Preprint version, Reference: Oliveira R, Rodrigues JP, Pereira JM, Lourenço PB, Marschall HU (2021), Normal and tangential behaviour of dry joints in refractory masonry. Engineering Structures, 243, 112600. https://doi.org/10.1016/j.engstruct.2021.112600

[12] Thanoon, W.; Alwathaf, A.; Noorzaei, J.; Jaafar, M.; Abdulkadir, M. "Finite element analysis of interlocking mortarless hollow block masonry prism". Computers and Structures, vol. 86, 2008, pp. $520-528$

[13] Belrhiti, Y.; Dupre, J.C.; Pop, O.; Germaneau, A.; Doumalin, P.; Huger, M.; Chotar, T. "Combination of Brazilian test and digital image correlation for mechanical characterization of refractory materials". Journal of the European Ceramic Society, vol. 37, 2017, pp. 2285-2293

[14] Dupré, J.C.; Doumalin, P.; Belrhiti, Y.; Khlifi, I.; Pop, O.; Huger, M. "Detection of cracks in refractory materials by an enhanced digital image correlation technique”. Journal of Materials Science, vol. 53, 2018, pp. 977-993

[15] Zahra, T.; Dhanasekar, M."Characterisation and strategies for mitigation of the contact surface unevenness in dry-stack masonry". Construction and Building Materials, vol. 169, 2018, pp 612-628 [16] Ngapeya, G.; Waldmann, D.; Scholzen, F. "Impact of the height imperfections of masonry blocks on the load bearing capacity of dry-stack masonry walls". Construction and Building Materials vol. 165,2018 , pp. $898-913$

[17] Agaajani, S. "Development and Investigation of a New Dry-Stacked Wall System", PhD thesis, University of Luxembourg, 2015, 265 pages.

[18] Brulin, J.; Blond, E.; Bilbao, E.; Rekik, A.; Landreau, M.; Gasser, A.; Colleville, Y. "Methodology for brick/mortar interface strength characterization at high temperature" Construction and Building Materials. vol. 265, 2020, 120565

[19] European Committee for Standardization (CEN)(2002) Methods of test for masonry - Part 3: Determination of initial shear strength, EN 1052-3, Brussels: CEN.

[20] Ramanenkaa, D.; Antti, M-L.; Gustafsson, G.; Jonsén, P."Characterization of high-alumina refractory bricks and modelling of hot rotary kiln behaviour". Engineering Failure Analysis, vol. 79, 2017, pp 852-864

[21] Gasser, A., Genty, F., Daniel, J. L.; Chen, L.; "Influence of different masonry designs of bottom linings". 13th Unified International Technical Conference on Refractories (UNITECR), VictoriaCanada, 2013, pp. 775-780

[22] Ali, M.; Sayet, T.; Gasser, A.; Blond, E. "Transient Thermo-Mechanical Analysis of Steel Ladle Refractory Linings Using Mechanical Homogenization Approach”. Ceramics, 2020, vol. 2, pp 171188 
Preprint version, Reference: Oliveira R, Rodrigues JP, Pereira JM, Lourenço PB, Marschall HU (2021), Normal and tangential behaviour of dry joints in refractory masonry. Engineering Structures, 243, 112600. https://doi.org/10.1016/j.engstruct.2021.112600

[23] Ali M.; Sayet, T.; Gasser, A. and Blond, E. "Thermomechanical Modelling of Refractory Mortarless Masonry Wall Subjected to Biaxial Compression”. Unified International Technical Conference of Refractories, Yokohama - Japan, 2019, pp. 205-208

[24] Ramanenka, D.; Stjernberg, J; Jonsén, P.; "FEM investigation of global mechanisms affecting brick lining stability in a rotary kiln in cold state", Engineering Failure Analysis, vol. 59, 2016, pp. 554-569

[25] Heindl, R.A.; Mong, L.E. "Young's modulus of elasticity, strength, and extensibility of refractories in tension”. J. Res. Natl. Bur. Stand, 17, 1936, pp. 463-482.

[26] Stuppfler, A.; Dahlem, E. "Investigation of the parameters influencing the refractoriness under load (RuL) testing results for refractory materials, Refract. Worldforum, 7, 2015, pp. 87-93.

[27] Dahlem, E.; Clasen, S.; Dannert, C. "Investigation of the factors influencing the bulk density and open porosity testing results for refractory materials", Refract. Worldforum, 7, 2015, pp. 95-104.

[28] Czechowski, J.; Gerle, A.; Podworny, J.; Dahlem, E. "Investigation of the testing parameters influencing the cold crushing strength testing results of refractory materials", Refract. Worldforum, 7 , 2015, pp. 105-112.

[29] Bakunov, V.S.; Belyakov, A.V.; Role of structural characteristics in high-temperature creep of ceramics, Refract. Ind. Ceram., vol. 41, 2000, pp. 349-355

[30] Callister, D.; Callister Jr., D. "Fundamentals of Materials Science and Engineering (2001), John Wiley \& Sons, Inc., 921 pages

[31] Ceylantekin, R.; Aksel, C. "The comparison of mechanical behavior of MgO-MgAl2O4 with MgO-ZrO2and MgO-MgAl2O4-ZrSiO4 composite refractories," Ceram. Int., vol. 38, no. 2, 2012, pp. 1409-1416

[32] Nath, M.; Tripathi, H.S. "Thermo-mechanical behavior of Al2O3-Cr2O3refractories: Effect of TiO2” Ceram. Int., vol. 41, no. 2, 2015, pp. 3109-3115.

[33] Mukhopadhyay, S.; Dana, K.; Moitra, S.; Basumallick, S.; Mukhopadhyay, T. K. "Thermal and thermomechanical characteristics of monolithic refractory composite matrix containing surfacemodified graphite," Ceram. Int., vol. 42, no. 5, 2016, pp. 6015-6024.

[34] Musante, L.; Martorello, L. F.; Galliano, P. G.; Cavalieri, A. L.; Martinez, A. G. "Mechanical behaviour of $\mathrm{MgO}-\mathrm{C}$ refractory bricks evaluated by stress-strain curves," Ceram. Int., vol. 38, no. 5, 2012, pp. 4035-4047. 
Preprint version, Reference: Oliveira R, Rodrigues JP, Pereira JM, Lourenço PB, Marschall HU (2021), Normal and tangential behaviour of dry joints in refractory masonry. Engineering Structures, 243, 112600. https://doi.org/10.1016/j.engstruct.2021.112600

[35] T. Prietl, "Ermittlung materialspezifischer Kennwerte von feuerfesten Werkstoffen und Zustellungen unter uni- und biaxialen Lastbedingungen für die Nichteisenmetallindustrie," $\mathrm{PhD}$ Thesis, University of Leoben, 2006, 192 pages.

[36] Prietl, T.; Zach, O.; Studnicka, H. "The evaluation of refractory linings thermomechanical properties". Erzmetall - World of metallurgy, 59, 2006, pp. 127-132

[37] Abaqus User Manual, Dassault Systems Simulia Corporation, 2010, USA.

[38] Lee, J.; Fenves, G. L. "Plastic-damage model for cyclic loading of concrete structures". J. Eng. Mech. 124 (8), 1998, pp. 892-900.

[39] Lubliner, J.; Oliver, J.; Oller, S.; Onate, E. “A plastic-damage model for concrete”. Int. J. Solids Struct., 25(3), 1989, pp. 299-329.

[40] Lourenço, P. B.; Mendes, N.; Ramos, L.F.; Oliveira, D.V. "Analysis of masonry structures without box behavior". Int. J Arch Heritage, 5, 2011, pp. 369-82

[41] Kaczmarek, R.; Dupre, J.C.; Doumalin, P.; Pop, I.O.; Teixeira, L.B.; Gillibert, J.; Blond E. and Huger, M. "Thermomechanical behaviour of an alumina spinel refractory for steel ladle applications". Unified International Technical Conference of Refractories, Yokohama - Japan, 2019, pp. 422-425

[42] Oliveira, R.; Rodrigues J. P.; Pereira, J. M. "The Characterization of joint Behaviour in Mortarless Refractory Masonry". In Proceedings of the Unified International Technical Conference of Refractories, Yokohama, Japan, 2019, pp. 612-614 